NBER WORKING PAPER SERIES

\title{
INTERNATIONAL EVIDENCE OF STRENGTHENING TAXES AND SPENDING FOR SUSTAINABLE DEVELOPMENT
}

\author{
Joshua Aizenman \\ Yothin Jinjarak \\ Hien Nguyen \\ Donghyun Park \\ Working Paper 29594 \\ http://www.nber.org/papers/w29594 \\ NATIONAL BUREAU OF ECONOMIC RESEARCH \\ 1050 Massachusetts Avenue \\ Cambridge, MA 02138 \\ December 2021
}

Joshua Aizenman is grateful for the support provided by the Dockson Chair in Economics and International Relations, USC. The views expressed herein are those of the authors and do not necessarily reflect the views of the National Bureau of Economic Research and the Asian Development Bank.

NBER working papers are circulated for discussion and comment purposes. They have not been peer-reviewed or been subject to the review by the NBER Board of Directors that accompanies official NBER publications.

(C) 2021 by Joshua Aizenman, Yothin Jinjarak, Hien Nguyen, and Donghyun Park. All rights reserved. Short sections of text, not to exceed two paragraphs, may be quoted without explicit permission provided that full credit, including $\odot$ notice, is given to the source. 
International Evidence of Strengthening Taxes and Spending For Sustainable Development Joshua Aizenman, Yothin Jinjarak, Hien Nguyen, and Donghyun Park

NBER Working Paper No. 29594

December 2021

JEL No. E62,F15,F34,O11

\begin{abstract}
$\underline{\text { ABSTRACT }}$
We trace the linkages between the episodes of fiscal expansion and consolidation in 72 advanced and emerging and developing economies. The findings suggest that fiscal expansions are positively associated with economic growth, which in turn is positively linked with better sustainable development outcomes. The association between fiscal consolidation and growth as well as the sustainable development indicators, however, is not clear-cut. Jointly, more tax revenues and expenditures, together with better governance help explain the association between economic growth and inclusive development. High-income, high-tax-revenue, and manufactureexporting economies have made significant progress on reducing disease-linked mortality and improving environment protection along with economic growth. Meanwhile, emerging and developing, low-tax-revenue, and commodity-exporting economies have gained notable improvement in poverty reduction, pre-primary enrolment and access to basic sanitation services and clean cooking fuels and technologies, and lowering bribery incidence. On average, the sampled economies have persistently achieved better primary goals such as sanitation, clean fuels and technologies. Achievements in mortality reduction, and environmental protection goals are shown more recently.
\end{abstract}

Joshua Aizenman

Economics and SIR

University of Southern California

University Park

Los Angeles, CA 90089-0043

and NBER

aizenman@usc.edu

Yothin Jinjarak

ERCD

Asian Development Bank

Mandaluyong City 1550

Metro Manila, Philippines

yothin.jinjarak@vuw.ac.nz
Hien Nguyen

School of Economics and Finance

Victoria University of Wellington

Rutherford House, Room 328

Wellington 6011

New Zealand

and The Treasury New Zealand

hien.nguyen@vuw.ac.nz

Donghyun Park

Economics and Research Department

Asian Development Bank

Manila, Philippines

dpark@adb.org 


\section{INTRODUCTION}

This paper studies the inter-temporal relationships between fiscal policy, economic growth, and sustainable development outcomes. For the former, we focus on domestic spending and revenue mobilization around large fiscal impulse episodes, defined as fiscal stimuli and fiscal consolidation. Large fiscal expansions, i.e., fiscal stimuli episodes are positively associated with increasing economic growth. However, fiscal consolidation typically has a negative short-run impact on outputs. ${ }^{1}$ Apart from economic growth, we also consider its conclusiveness and sustainability by examining 17 key sustainable development indicators. We find that economic growth is also positively correlated with better sustainable development outcomes. Furthermore, fiscal policy can be a potential instrument to foster a country's sustainable development through economic growth. Higher tax revenue and expenditure as well as higher-quality governance can boost economic growth, and in turn, increasing growth promotes sustainable development outcomes.

In this study, we take advantage of a panel dataset covering 72 advanced economies (ADV) as well as emerging and developing economies (EME) over the 1991-2019 period to shed some light on those linkages. This paper is an extension of our previous working paper version providing case studies of 4 emerging economies including Chile, Poland, South Africa, and Thailand. ${ }^{2}$ The approach we are applying in this study is different by focusing on the panel results and the linkages between fiscal policy, economic growth, and sustainable development indicators. We also examine the impact of economic growth on sustainable development outcomes in sub-groups of economies taking into account countries' level of development, tax revenue, and debt, as well as economic structure.

In particular, we ask three questions. First, we examine the relationship between fiscal policy, i.e., large fiscal impulse episodes, and economic growth by considering their possible two-way relationship. Second is the association between economic growth and sustainable development outcomes, taking into consideration countries' levels of development, tax revenue, and public debt as well as exporting structure. Third, we address the role played by fiscal policy and country-specific political variables to explain economic growth as delivering better sustainable development outcomes. In an extended analysis, we reveal the historical impacts of economic growth on selected

\footnotetext{
${ }^{1}$ Gupta (2021) reviews the extensive literature on the short-term to medium- and long-term impact of fiscal adjustment on growth.

${ }^{2}$ See our previous NBER working paper version at https://www.nber.org/papers/w28740.
} 
sustainable development indicators since 2000 , which sheds some light on how the strategy of development goals changes over time in the sampled countries.

By applying different regression approaches including fixed-effects, seemingly unrelated regression (SUR), and two-stage least squares (TSLS), our findings are robust and consistent. First, we find that fiscal expansion episodes are beneficial to delivering economic growth in the next period whereas higher economic growth lowers the need of conducting fiscal expansion in the next period. We find no significant evidence on the relationship between economic growth and fiscal consolidation episodes. Second, economic growth is also found to significantly enhance sustainable development outcomes in the short term. This result remains robust under a scenario of limited resources reasonably facing most countries. Dividing the sample by level of development, tax revenue, and public debt as well as economic structure, we find some different patterns in the impact of economic growth on sustainable development indicators. The high-income economies, high-tax-revenue economies, and manufacturing exporters have gained notable improvement in mortality reduction and protecting the environment as their GDP increases. On the other hand, emerging and developing economies, low-tax-revenue economies, and commodity exporters have noticeably enhanced the primary goals such as poverty reduction, increasing enrolment and access to basic sanitation services and clean fuels and technologies for cooking as well as lowering bribery incidence in public transactions. Third, we also find that tax revenue, primary expenses, political rights, and government effectiveness could be good instrumental variables for economic growth as explaining the improvement of sustainable development outcomes, though they are not a great fit in all cases. Last but not least, we find that the sampled countries allocated their resources to the development goals differently since 2000 . The primary necessities such as basic sanitation services and clean fuel and technology for cooking have been improved persistently whereas better performance in reducing mortality rate due to diseases and protecting the evironment can be seen more recently. 


\section{METHODOLOGY}

\section{A. Data}

Our sample comprises 72 countries (35 advanced and 37 emerging and developing) covering the 1991-2019 period (unbalanced). The studied sample mainly depends upon data availability of the key components of general government spending and tax revenue which are used to estimate fiscal episodes. In particular, a country is included if having at least 10 continuous observations on those components.

Data on the general government spending components are from Government Finance Statistics database of the International Monetary Fund, including wage bills (Wage), nonwage expenditure (Nonwage), subsidies to firms (Subsidies), and expenditure on social benefits (Transfers); all in percent of GDP. Due to the shortage of data on fixed capital consumption, i.e., there are 29 out of 72 sampled countries having fewer than 10 observations during the 1991-2019 period (see Appendix), we exclude that component from the study. This exclusion should not influence our analysis as the fixed capital consumption is only a minor part of the general government expenditure (from $0 \%$ up to $4.7 \%$ (in Latvia) on average over the 1991-2019 period, varying across countries). Following the literature, we also exclude interest expense to focus on the discretionary change of fiscal impulse. Our data indicate that the interest expense varies across countries and accounts for a small fraction of the general government expenses (from approximately 0\% (in Macao) up to $8.3 \%$ (in Brazil) on average over the 1991-2019 period).

We use the Government Revenue Dataset of the United Nations University World Institute for Development Economics Research (UNU-WIDER) for the main components of total tax revenue. The data include personal income taxes $(P I T)$, corporate income taxes $(C I T)$, payroll and workforce taxes and property taxes (Other), indirect taxes (INDT), and social security contributions (SSC); all in percent of GDP.

Using those key expense and tax components, the fiscal indicators including total tax revenue, primary expenses, and primary deficit are calculated as follows:

- $\quad$ Total tax revenue $(\%$ of GDP $)=P I T+C I T+$ Other $+I N D T+S S C$

- $\quad$ Primary expenses $(\%$ of GDP $)=$ Wage + Nonwage + Subsidies + Transfer 


\section{- $\quad$ Primary deficit $(\%$ of GDP) $=$ Primary expenses - Total tax revenue}

Our analysis considers economic growth, taking into account its inclusivity and sustainability. For comprehensiveness, we also focus on 17 Sustainable Development Goals (SDGs) indicators, covering poverty headcount ratio (Poverty); population share of undernourished (Undernourishment); mortality ratio from cardiovascular disease, cancer, diabetes, or chronic respiratory disease between age 30 and age 70 (Mortality); enrollment ratio to pre-primary school (Enrollment); proportion of seats held by women in national parliaments (Women power); population share with access to basic sanitation services (Sanitation); population share with access to clean fuels and technologies for cooking (Fuel-Tech); youth population share not in education, employment or training (Noneducation); fixed broadband subscriptions (Broadband); mean consumption of bottom $40 \%$ of population (Bottom consumption); exposure to atmospheric particulate matter (PM) that have a diameter of less than 2.5 micrometers or $\mathrm{PM}_{2.5}$ air pollution (Pollution); carbon dioxide damage (Carbon dioxide damage); number of displaced persons associated with disasters (Displacement); marine protected areas (Marine); terrestrial protected areas (Terrestrial); bribery incidence experienced by firms (Bribery); and personal remittances (Remittances). We collect the annual data from World Bank's World Development Indicators database.

Note that, for government spending, tax revenue, and SDGs variables, we reasonably fill up the missing data using other indicators and/or linear interpolation. Other than that, unemployment rate is used to define large fiscal expansion and consolidation episodes. Data on unemployment rate is from World Bank's World Development Indicators database.

We also take into account the role of development level, total tax revenue, public debt, economic structure, and political economy in the association between economic growth and sustainable development outcomes. Note that we divide the studied sample into sub-groups based on their development level (ADV versus EME), tax revenue level (high-tax-revenue versus low-tax-revenue economies), debt level (high-debt versus low-debt economies), and economic structure (manufacturing exporters versus commodity exporters). For tax revenue, an economy is classified to belong to a high (low) tax revenue group if their average total tax revenue (\% of GDP) over the 19912019 period is higher (lower) than the sampled median tax revenue contribution in GDP, which is 28.8\% of GDP. We apply similarly to classify high (low) debt economies using the sampled median debt of $42.7 \%$ of GDP. Data on public debt (as percentage of GDP) is sourced from International 
Monetary Fund's Historical public debt database. For the export structure, a country will be classified to be a commodity exporter and/or manufacturing exporter using their trade balance (in percent of GDP) of commodity (including agricultural raw materials, food, fuel, ores and metals) and manufactures. In particular, a manufacturing (commodity) exporter has a positive trade balance (\% of GDP) of manufactures (commodity) over the 1991-2019 period. Annual data on exports and imports are also from World Bank's World Development Indicators database. We include two proxies of political quality: political rights sourced from Freedom House's Freedom in the World database and government effectiveness sourced from the PRS group's International Country Risk Guide database. Details of all variables and interpolation are in the Appendix.

\section{B. Identifying fiscal episodes}

To estimate fiscal episodes, we use data on the main components of the general government spending, tax revenue, and unemployment rate.

Following Alesina and Ardagna (2010) and Alesina and Perotti (1995), we define fiscal episodes using the significant change in the primary deficit (as a share of GDP) from the previous year. The underlying assumption is that the unemployment rate remained stable in period $t$ as in period $t-1$. According to Blanchard (1993), this approach takes the previous year as the benchmark period ( $t-1)$ and estimates the government expenses and tax revenue in the current year $(t)$, thereby filtering out the variations in fiscal variables induced by business cycle fluctuations. Subject to data availability, we follow this approach for simplicity, avoiding the challenges posed by countryspecific calculation of potential outputs.

We define the cyclically-adjusted variables and episodes of large fiscal impulse as follows:

- Cyclically-adjusted Primary expenses (\% of GDP) = Cyclically-adjusted Transfer + (Wage + Nonwage + Subsidies)

- $\quad$ Cyclically-adjusted Total tax revenue (\% of GDP) = Cyclically-adjusted PIT + Cyclicallyadjusted CIT + Other + Cyclically-adjusted INDT + Cyclically-adjusted SSC

- $\quad$ Cyclically-adjusted Primary deficit (\% of GDP) = Cyclically-adjusted Primary expenses Cyclically adjusted Total tax revenue

- $\quad$ Fiscal impulse $\left(\%\right.$ of GDP) $=$ Cyclically adjusted Primary deficit $t_{t}-$ Primary deficit $_{t-1}$ 
We correct each of the fiscal variables at period $t$ (denoted as $X_{t}$ ) the variations caused by cyclical factors. For each country in the sample, we first regress each fiscal variable $\left(X_{t}\right)$ on a time trend $\left(T R E N D_{t}\right)$ and the unemployment rate $\left(U_{t}\right)$.

$$
X_{t}=\alpha_{0}+\alpha_{1} \operatorname{TREND} D_{t}+\alpha_{2} U_{t}+\varepsilon_{t}
$$

Next, we estimate what each fiscal variable would be in period $t$ if the unemployment rate were to remain the same as in the previous year $\left(U_{t-1}\right)$, i.e., the cyclically-adjusted fiscal variable.

$$
X_{t}\left(\text { at } U_{t-1}\right)=\widehat{\alpha_{0}}+\widehat{\alpha_{1}} \operatorname{TREND} D_{t}+\widehat{\alpha_{2}} U_{t-1}+\widehat{\varepsilon_{t}}
$$

where the terms, $\widehat{\alpha_{0}}, \widehat{\alpha_{1}}, \widehat{\alpha_{2}}$, and $\widehat{\varepsilon_{t}}$ are coefficient estimates.

Having estimated $\operatorname{Transfer}_{t}\left(\right.$ at $\left.U_{t-1}\right), \operatorname{PIT}_{t}\left(\right.$ at $\left.U_{t-1}\right), \operatorname{CIT}_{t}\left(\right.$ at $\left.U_{t-1}\right), \operatorname{INDT}_{t}\left(\right.$ at $\left.U_{t-1}\right)$, and $S_{S S}\left(\right.$ at $\left.U_{t-1}\right)$, we calculate Primary expenses ${ }_{t}\left(\right.$ at $\left.U_{t-1}\right)$, Total tax revenue rat $\left._{t-1}\right)$, and then Primary deficit $t_{t}\left(a t U_{t-1}\right)$. The Fiscal impulse at period $t$ is the difference between the cyclically-adjusted primary deficit at period $t$ [Primary deficit $t_{t}\left(\right.$ at $\left.U_{t-1}\right)$ ] and the actual primary deficit at period $t-1$ [Primary deficit $\left.{ }_{t-1}\right]$.

We estimate fiscal impulse for each country that has at least 10-year continuous observations of expenses and tax revenue components and identify episodes of large fiscal impulse (discretionary fiscal policy): fiscal consolidation and fiscal stimuli as follows:

- $\quad$ strong fiscal consolidation, i.e., Fiscal consolidation gets value 1 if Fiscal impulse (\% of GDP) is less than - 1.5 and 0 otherwise;

- $\quad$ strong fiscal stimuli, i.e., Fiscal stimuli gets value 1 if Fiscal impulse (\% of GDP) is larger than 1.5 and 0 otherwise.

Our data show that the longest fiscal episodes persisted for 3 years (fiscal stimuli in Macao SAR, China during 2014-2016 and Norway 2001-2003 and fiscal consolidation in Cabo Verde during 2006-2008, Congo, Rep. during 2008-2010 and Greece during 2016-2018). We also found many fiscal stimuli episodes to occur during the 2008-2009 global financial crisis and many fiscal consolidations during the 2010-2011 post-global crisis period.

\section{Linking fiscal policy, economic growth, and sustainable development}


The main questions of this research focus on the short-term linkages between fiscal policy, economic growth, and sustainable development outcomes as well as the underlying determinants of those linkages. Accordingly, we aim to investigate the following hypotheses:

(I) Hypothesis 1: Fiscal stimuli (consolidation) episodes have a positive (negative) impact on economic growth.

(II) Hypothesis 2: Higher economic growth lowers (elevates) the need for fiscal stimuli (consolidation) episodes.

(III) Hypothesis 3: Higher economic growth favors sustainable development.

First, to examine Hypothesis 1, we conduct fixed-effects regressions using the following equations on the short-term association between economic growth and large fiscal impulse episodes:

$$
\Delta d \ln G D P_{i t}=\alpha_{0}+\alpha_{1} \text { Fiscal Episode } e_{i t-1}+\varepsilon_{i t}
$$

For Hypothesis 2 on the reversed direction, we regress the following equation using both probit and logit regressions with random effects as the dependent variables are binary:

$$
\text { Fiscal Episode } e_{i t}=\beta_{0}+\beta_{1} \Delta d \ln G D P_{i t-1}+\epsilon_{i t}
$$

, where $\Delta d \ln G D P_{i t}$ is the first-difference of GDP growth rate of country $i$ in year $t$, Fiscal Episode is either Fiscal stimuli or Fiscal consolidation episodes, the parameters $\alpha_{0}, \alpha_{1}, \beta_{0}, \beta_{1}$ are coefficients to be estimated, and $\varepsilon_{i t}, \epsilon_{i t}$ are the residuals. We use one-year lag values for the independent variables in equations (3) and (4).

Second, to examine Hypothesis 3 on the linkages between economic growth and sustainable development indicators, we regress the following equation using fixed-effects:

$$
\operatorname{lnSDGs} s_{i t}=\gamma_{0}+\gamma_{1} \operatorname{lnGDP_{it-1}}+\vartheta_{i t}
$$

As an important cross-check, we re-regress equations (5) using SUR to control for the possible correlation between the residuals of 17 separate equations. We would argue that the effects of GDP on each SDG could be driven by GDP or resource limitation and allocation, which could be reflected in each equation's residuals.

In a further step to extend equation (5) above, we link SDGs, economic growth, fiscal policy, and country-specific political characteristics by re-regressing equation (5) using TSLS approach. In the first stage, economic growth is instrumented by a fiscal variable which is either total tax revenue or 
primary expenses (all in natural logarithm), and a political variable which is either political rights or government effectiveness.

$$
\operatorname{lnGDP}_{i t-1}=\theta_{0}+\theta_{1} \text { Fiscal policy }_{i t-2}+\theta_{2} \text { Political quality }_{i t-2}+u_{i t}
$$

Detailed results are reported in the following section. Note that the results in other cross-checks using GDP per capita as an alternative to GDP as controlling for population growth and including time trend are robust and consistent with the baseline findings. To save space, those robustness checks will be provided upon request.

\section{RESULTS}

\section{A. Stylized facts}

In the figures below, we show the first glance of the correlations between SDGs and total tax revenue and primary expenses, averaged over 1991-2019 for the whole sample of 72 countries.

\section{[Insert Figure 1]}

We start by simply plotting the total tax revenue (\% of GDP) and sustainable development indicators average over the 1991-2019 period by country in Figure 1 and find that countries with higher tax revenue contribution in GDP tend to have better sustainable development proxies such as lower poverty headcount ratio, lower undernourishment ratio, higher enrolment rate, more people having access to basic sanitation services as well as clean fuels and technologies for cooking, etc.

[Insert Figure 2]

Next, as plotting average primary expenses (\% of GDP) and sustainable development indicators by country in Figure 2, we also find the positive associations between larger general government spending and sustainable development performance, for example, higher consumption for the bottom $40 \%$ of the population and more access to fixed broadband. Though those association patterns between tax revenue, primary expenses, and sustainable development variables revealed in Figures 1-2 could be useful, the two fiscal variables are highly correlated, and hence including both in one regression will be troublesome. As you can see in Section III.D, we include one at a time in estimation for the relationship between fiscal policy and sustainable development. [Insert Figure 3] 
In addition, as suspecting of the possible correlation between fiscal policy and country-specific political quality, in Figure 3, we plot total tax revenue and primary expenses (all in \% of GDP) and three political variables including political rights, government effectiveness, and ethnic power relations. All of the fiscal and political variables are averaged over the 1991-2019 period except the latter whose 2020 data is used due to data limitation. We find that higher tax revenue and expenses are positively correlated with more free political rights and higher government effectiveness. The relationship of fiscal variables and the power of the largest ethnic political group is not clear though. For this reason and also due to data unavailability of ethnic power relations, we will focus on political rights and government effectiveness in the subsequent empirical sections. [Insert Figure 4]

Apart from the relationship between sustainable development, fiscal policy, and political quality, we also focus on one of the traditional questions - the relationship between fiscal policy and economic growth. The first overview is shown in Figure 4 plotting GDP growth rate, total tax revenue, and primary expenses (all in \% of GDP) by country over the 1991-2019 period. Overall, we find a negative association between GDP growth and tax revenue as well as primary expenses in all sub-groups (ADV versus EME; high- versus low-tax-revenue economies; high versus low-debt economies; manufacturing and commodity exporters), and no significant difference is detected across those sub-groups of economies. The estimation results exploiting fiscal episodes in the following section may shed some light on those relationships.

\section{B. Fiscal episodes and economic growth}

In this section, we report the regression results on the two-way relationship between fiscal episodes and economic growth.

[Insert Table 1]

Table 1 reports the estimates of equation (3) for the impact of fiscal episodes (fiscal stimuli and fiscal consolidation) on GDP growth using fixed-effects approach. When year dummies are excluded, we find a positive and significant association between the current first-differenced GDP growth rate and lagged fiscal stimuli. In particular, fiscal stimuli in the previous year are associated with a $1.8 \%$ increase in GDP growth rate in the current period, on average. Fiscal consolidation is negatively associated with GDP growth rate; however, the coefficient is not statistically significant. The results become insignificant as year dummies are included.

[Insert Figure 5] 
In Figure 5, we explore further the impact of fiscal episodes on economic growth in sub-groups using fixed-effects regression results when year dummies are excluded. Note that, We find that, fiscal stimuli episodes tend to have a larger positive impact on GDP growth in emerging and developing economies (than in advanced economies), on low-tax-revenue economies (than in hightax-revenue economies), in high-debt economies (than in low-debt economies), and in manufacturing exporters (than in commodity exporters). Specifically, fiscal stimuli episodes in the previous year are associated with a $2.5 \%$ increase in GDP growth rate in the current period in EME and $1.3 \%$ in ADV, $2.8 \%$ in low-tax-revenue economies and $1.0 \%$ in high-tax-revenue economies, $2.3 \%$ in high-debt economies and $1.4 \%$ in low-debt economies, $2.9 \%$ in manufacturing economies and $1.5 \%$ in commodity economies. The impact in commodity exporters, as well as the differences in the growth impact of fiscal stimuli across those sub-groups are not statistically significant though. For fiscal consolidation episodes, we found the contraction impact on growth in EME, low-taxrevenue economies, high-debt economies, and commodity exporters whereas the expansion impact in ADV, high-tax-revenue economies, low-debt economies, and manufacturing exporters. Only the association in manufacturing exporters is statistically significant though. [Insert Table 2]

Table 2 summarizes the estimates of equation (4) for the impact of GDP growth on fiscal episodes by probit regression in columns (1)-(2) and by logit regression in columns (3)-(4). The two approaches deliver a consistent finding that increasing GDP growth in the previous year is associated with a lower probability of fiscal stimuli episodes in the current year (see columns (1) and (3)). Given that the first-differenced GDP growth in the previous year is at its mean value ($0.05 \%)$, the probability of fiscal stimuli occurrence in the current year is $12 \%$ predicted by both probit and logit regressions, and a 1\% increase in lagged GDP growth compared to its previous year is associated with a $0.6 \%$ decrease in the chance of having fiscal stimuli next year. However, the association between GDP growth rate and fiscal consolidation episodes is not statistically significant (see columns (2) and (4)).

\section{Economic growth and sustainale development}

Before regressing equation (5), we plot the histograms of 17 SDG indicators and constant GDP both in raw data and in natural logarithm form (see Appendix Figures $A 1$ and $A 2$ ). Figure $A 1$ shows that most of their distributions are far from normal distributions whereas, in Figure $A 2$, most of the distributions of the SDG indicators and constant GDP appear to follow normal distribution except 
Undernourishment, Enrollment, Sanitation, Fuel-Tech, Broadband, among the others. Therefore, we proceed with regressing equation (5) on those variables using their natural logarithm.

[Insert Table 3]

In Table 3, we report the estimates showing the impact of economic growth on 17 SDG indicators. We found that increasing GDP in the previous year is associated with lower poverty headline ratio, lower undernourished population ratio, lower mortality rate due to cardiovascular disease, cancer, diabetes, or chronic respiratory disease, lower non-educated youth population ratio, lower $\mathrm{PM}_{2.5}$ air pollution, lower carbon dioxide damage in gross national income, lower displacement cases due to disasters, lower percentage of firms experiencing bribery, higher enrolment ratio at pre-primary school, higher women shares in national parliaments, higher population ratio having access to basic sanitation services as well as clean fuels and technologies for cooking, higher broadband subscription rate, higher consumption for bottom $40 \%$ population, larger marine and terrestrial protected areas, and higher remittances in GDP. Most of the estimates are expected except Displacement whose coefficient is not statistically significant.

In particular, a $1 \%$ increase of GDP in the last year is associated with a $1 \%$ decrease in poverty headcount ratio, a $0.4 \%$ decrease in the population ratio living below minimum level of dietary energy consumption, a $0.5 \%$ decrease in mortality ratio of those aged $30-70$ years old due to cardiovascular sidease, cancer, diabetes, or chronic respiratory disease, a $0.4 \%$ increase in gross enrolment ratio at pre-primary education level, a $0.8 \%$ increase in women' seats ratio in national parliaments, a $0.1 \%$ increase in population ratio using at least basis sanitation services, a $0.3 \%$ increase in population ratio having access to clean fuels and technologies for cooking, a $0.4 \%$ decrease in youth population share not in education, employment or training, a $6.7 \%$ increase in fixed broadband subscriptions per 100 people, a $0.9 \%$ increase in consumption of bottom $40 \%$ population, a $0.2 \%$ decrease in $\mathrm{PM}_{2.5}$ air pollution mean annual exposure, a $0.5 \%$ decrease in carbon dioxide damage in gross national income, a $1.8 \%$ increase in marine protected areas in the territorial waters, a $0.5 \%$ increase in terrestrial protected areas in total land area, a $1.6 \%$ decrease of bribery incidence ratio for firms, and a 1.2\% increase in received personal remittances in GDP.

\section{[Insert Figure 6]}

As poverty reduction is one of the most important goals for sustainable development, in Figure 6, we specifically look at the poverty impact of economic growth across sub-groups of economies. 
While the association between growth and poverty is insignificant in ADV, economic growth is strongly associated with poverty reduction in EME, i.e., a 1\% increase of GDP in the previous year is associated with a $1.2 \%$ decrease in poverty headcount ratio. The impacts are larger in low-taxrevenue economies (1\%) than in high-tax-revenue economies (0.8\%), in low-debt economies (1.1\%) than in high-debt economies (0.8\%), and in manufacturing exporters $(1.8 \%)$ than in commodity exporters (1.2\%) though these differences are not statistically significant.

[Insert Figure 7]

In Figure 7, we access the impact of economic growth on the other 16 SDG indicators by sub-group of economies by plotting their mean estimates and $95 \%$ confidence intervals. For

Undernourishment ratio, we find a negative association with economic growth in most of the subgroups (except high-debt economies and manufacturing exporters) without statistically significant difference between sub-groups. However, for Mortality ratio, significantly larger negative associations are found in ADV (than in EME), high-tax-revenue economies (than in low-tax-revenue economies), and in manufacturing exporters (than in commodity exporters) whereas the impact in high-debt economies are indifferent from that in low-debt economies. We also found positive associations between Enrolment ratio and economic growth in all sub-groups with a larger impact in EME than in ADV. The positive impact of economic growth on the access ratio to basic Sanitation services is larger and statistically distinguishable in EME (than in ADV) and in commodity exporters (than in manufacturing exporters). For the access ratio to clean Fuel-Tech for cooking, we find significant positive and larger impacts of economic growth in EME (than in ADV), low-tax-revenue economies (than in high-tax-revenue economies), and in commodity exporters (than in manufacturing exporters). The associations between economic growth and Pollution are negative in all sub-groups; larger impacts are found in ADV (than in EME), high-tax-revenue (than in low-taxrevenue), and in manufacturing exporters (than in commodity exporters). For Marine protected areas, we find a positive impact of economic growth in ADV and low-debt economies but insignificant in EME, high-debt economies, and other sub-groups. The positive association of economic growth and Terrestrial protected area is only detected in ADV and insignificant in the other sub-groups. For Bribery incidence, we find a negative and significant association with economic growth in EME, low-tax-revenue economies, and low-debt economies but insignificant in other sub-groups. We also find positive associations of Remittances and economic growth in most of the sub-groups except low-tax-revenue economies and commodity exporters. For other SDG 
indicators, we find that economic growth is positively associated with Women power, Broadband, Bottom consumption and negatively associated with Non-education, Carbon dioxide damage in all sub-groups of economies but the differences are not statistically significant between sub-groups. We also find an insignificant association between economic growth and Displacement ratio.

In addition, we report the mean values of SDG indicators over the 1991-2019 period by sub-group of economies and the mean comparison tests in Appendix Table A2. As can be seen and not surprising, the ADV, high-tax-revenue economies, low-debt economies, and manufacturing exporters show better sustainable development performance on average compared to their counterparts, for example, lower poverty headcount ratio, lower undernourishment ratio, lower mortality ratio associated with cardiovascular disease, cancer, diabetes, or chronic respiratory disease, higher enrolment ratio (except low-debt economies having a lower enrolment ratio), higher proportion of women seats in parliaments (except manufacturing exporters having a lower proportion), higher access ratio to basic sanitation services and clean fuels and technologies for cooking, lower non-education ratio, higher broadband subscription ratio, higher consumption of the bottom $40 \%$ of population, lower displacement ratio associated with disasters, higher marine and terrestrial protected areas (except high-debt economies having larger terrestrial protected area), lower bribery incidence, and lower remittances received. However, it is quite debatable to see that the ADV, high-tax-revenue economies, and manufacturing exporters show lower pollution exposure and lower damage costs due to carbon dioxide emissions (also including high-debt economies). Last but not least, the ADV, high-debt economies, and manufacturing show higher real GDP averaged over the studied period.

Overall, we find some differences in the sustainable development performance across the groups of economies. The ADV, high-tax-revenue economies, and manufacturing exporters have gained better outcomes in reducing mortality ratio related to diseases and pollution exposure as well as increasing marine and terrestrial protected areas along with economic growth. However, their counterparts including EME, low-tax-revenue economies, and commodity exporters show better improvement in primary goals such as poverty reduction, increasing enrolment as well as access ratio to basic sanitation services and clean fuels and technologies for cooking. They also reveal a significant reduction in bribery incidence compared to their counterparts. For the high-debt economies and low-debt economies, we find undistinguishable evidence in their associations of economic growth and SDG indicators. 
[Insert Table 4]

In one extended step, we rerun equation (5) using SUR to control for the possibly correlated errors from each sustainable development indicator regression, we would like to address the limited GDP resource facing most countries. In this case, we drop the sustainable development indicators with very limited data observations including Poverty, Bottom_consumption, Displacement, Marine, Terrestrial, and Bribery, and focus on the rest. As the SUR approach requires strongly balanced data, we are left with 628 observations. The detailed regression results are reported in Table 4 with the sign and magnitude of the estimates are consistent with fixed-effects regression coefficients, except that Remittances estimate is still positive but no longer statistically significant.

We find from SUR estimates that lagged GDP is positively associated with enrolment rate at preprimary school, women seat shares in national parliaments, population ratio having access to basic sanitation services as well as clean cooking fuel and technologies, and fixed broadband subscription rate. Lagged GDP is also negatively associated with the undernourished population ratio, mortality rate from cardiovascular disease, cancer, diabetes, or chronic respiratory disease, non-educated youth population ratio, $\mathrm{PM}_{2.5}$ air pollution as well as carbon dioxide damage from fossil fuel use and cement manufacture in gross national income.

\section{Fiscal policy, growth, and sustainable development}

From the sections above, we find that fiscal stimuli episodes play an important role to explain GDP growth and in turn, GDP growth is strongly associated with sustainable development. In this section, we link those three factors including fiscal policy, growth, and sustainable development in TSLS regressions by instrumenting GDP by a fiscal variable and a country-specific political variable in the first stage, as described in equation (6). For the fiscal policy, we use the natural logarithm of either total tax revenue or primary expenses. Those two fiscal variables are not supposed to enter the same regression due to their strong correlation. The same rationale is considered for the political quality proxies as we use either political rights or government effectiveness, one at a time. Ethnic power relations are excluded due to their data unavailability for this panel study. We also conduct three post-estimation tests including weak instrumental variables (IVs) test (or first-stage F-test), overidentifying restrictions test, and endogeneity test. The estimates and post-estimation test results are reported in Table 5 for using total tax revenue and political rights as IVs and Table 6 
for using primary expenditure and political rights as IVs. As the results for government effectiveness are very similar, they are reported in Appendix Tables A3-A4.

[Insert Table 5]

As seen in Table 5, the correlations between GDP and SDG indicators are consistent with the estimates from fixed-effects and SUR approaches. We find that increasing GDP in the previous year is negatively associated with Poverty, Undernourishment, Mortality, Non-education, Pollution, Carbon dioxide damage, Displacement, and Bribery, and positively associated with Enrollment, Women power, Sanitation, Fuel-Tech, Broadband, and Bottom consumption, Marine, and Remittances. However, the post-estimation tests show that several regression results should be taken with a grain of salt. Ideally, we want (i) the p-value of first-stage F-statistics to be significant and F-statistics to be larger than 10; (ii) p-value of the overidentifying test is large; and (iii) p-value of endogeneity test is large so that the instrumental variables explaining for constant GDP, are valid instruments, i.e., they are uncorrelated with the error terms and correctly excluded from the estimate equation, and can actually be treated as exogenous. Note that the overidentifying test and endogeneity test fail in the case of Poverty, Mortality, Enrollment, Women power, Sanitation, FuelTech, Non-education, Broadband, Bottom consumption, Pollution, Terrestrial, Bribery, and Remittances. These findings suggest that the IVs could be a great fit for some SDG indicators but not all. Overall, we find that the IVs work well in the case of Undernourishment, Carbon dioxide damage, Displacement, and Marine satisfying all the post-estimation tests with the estimates having consistent signs as well as magnitude compared to fixed-effects and SUR estimates. [Insert Table 6]

Table 6 reports TSLS estimates in which GDP is instrumented by primary expenses and political rights in the first stage. We find that they are good instruments for GDP in the case of Undernourishment, Bottom consumption, and Carbon dioxide damage, Marine, and Terrestrial. However, the overidentification and endogeneity tests fail in other cases, meaning that their interpretation should be taken with caution although the associations between those SDG indicators and economic growth are consistent with the baseline fixed-effects estimates.

The TSLS results reported in Appendix Tables A3-A4 using either total tax revenue or primary expenses and government effectiveness as IVs for GDP show similar findings. These instruments are valid in the case of Undernourishment and Carbon dioxide damage in Table A3 and 
Undernourishment, Bottom consumption, Displacement, and Marine in Table A4. The estimates show that GDP is negatively associated with the undernourished population ratio and carbon dioxide cost of damage, and displaced population ratio due to disasters, and positively associated with consumption of the bottom $40 \%$ of population as well as marine protected areas.

Though our instrument variables are not a great fit for all cases, we find that they help explain GDP variations of the sampled countries. The first-stage estimates shown in Tables 5-6 and Appendix Tables A3-A4 show the positive association between GDP and tax revenue, primary expenses, political rights, and government effectiveness. Our TSLS estimations shed some light on the linkages between fiscal policy, political quality, economic growth, and sustainable development. In general, countries having larger total tax revenue, larger primary expenses, and better political economy tend to show higher economic growth, which in turn boosts up sustainable development performance.

\section{E. Historical impacts of growth on sustainable development}

In this section, we re-regress equation (5) using 20-year window rolling fixed-effects regressions and visualize the historical impacts of growth on selected sustainable development indicators with sufficient data in the post-2000 period.

[Insert Figure 8]

The SDG indicators consistently having negative associations with GDP from 2000 till the end of the studied period include Undernourishment and Mortality whereas Poverty, Non-education, Pollution, and Carbon dioxide damage show a negative association with GDP since 2007 or even later (Pollution since 2011). While the negative association of GDP and poverty reduction remains flat since being significant, the negative association with the undernourished population ratio becomes more contracted along the line, which is not surprising. On the contrary, the negative association with mortality ratio linked to diseases appears to be contracted till 2009 before becoming stronger since then. The negative association with non-educated youth ratio has also remained flat since 2010. However, the negative association between GDP and pollution exposure tends to be remarkably echoed since 2010 whereas carbon dioxide cost of damage shows a negative and contracted association with GDP recently after a strikingly large association since 2006. 
The SDG indicators showing a persistent and positive association with GDP are Enrollment, Women power, Sanitation, Fuel-tech, and Broadband. While the association with enrollment ratio and fixed broadband subscriptions tend to be weakened, an oppositive pattern is found in the case of access ratio to basic sanitation services and clean fuels and technologies for cooking with stronger association along the way. The association of GDP and women power in national parliaments also appears to be contracted. Last but not least, the positive association with remittances received seems to follow a quadratic trend with a stronger correlation from 2005 to 2015 before falling recently.

In general, our findings reveal the sustainable development goals showing more notable achievement in the sampled countries. Those economies have had more population to have access to primary necessities such as basic sanitation services and clean fuels and technologies for cooking. The results also show better performance in reducing mortality rate associated with diseases. In particular, other environmental goals such as reducing pollution exposure and cost of damage due to carbon dioxide emissions also reveal better achievement more recently. 


\section{CONCLUSION}

The past decades have shown improvements in sustainable development outcomes across countries. In this paper, we ask if those favorable outcomes are inter-temporally linked to economic growth and fiscal strategy. Our panel data analysis finds that fiscal policy remains an important instrument to boost economic growth and inclusive development indicators in the short term. In particular, fiscal expansion episodes in the previous year are associated with a $1.8 \%$ increase in GDP growth in the current year, and higher GDP growth is also positively associated with better sustainable development outcomes. Fiscal consolidation has a negative association with economic growth although their relationship is not significant. On the reversed direction, a $1 \%$ increase in GDP growth tends to lower $0.6 \%$ the chance of having fiscal stimuli in the next period. The association between economic growth and sustainable development indicators could be explained by fiscal policy (including total tax revenue and primary expenses in this study) as well as political quality (political rights and government effectiveness).

In addition, we also examine the impact of economic growth on sustainable development outcomes in sub-groups of economies by taking into account the countries' development level, total tax revenue, and public debt (in percentage of GDP) as well as economic structure. Several differences are detected. As GDP grows, the high-income, high-tax-revenue, and manufacture-exporting economies have achieved better results in lowering the mortality rate due to cardiovascular disease, cancer, diabetes, or chronic respiratory disease and protecting the environment by reducing $\mathrm{PM}_{2.5}$ air pollution exposure, increasing marine and terrestrial protected areas. On the other side, emerging and developing, low-tax-revenue, and commodity-exporting economies achieve better outcomes in primary goals such as reducing poverty, increasing enrolment ratio at pre-primary education level, gaining more access to basic sanitation services and clean cooking fuels and technologies, as well as lowering bribery incidence in public transactions. However, we find immaterial differences between high-debt and low-debt economies in their sustainable development performance associated with economic growth.

Furthermore, as analyzing the historical impact of economic growth on sustainable development outcomes since 2000, we find that the sampled economies have made remarkable progress on different development goals over time. On average, the economies show a consistent improvement in access to basic sanitation services and clean cooking fuels and technologies whereas the notable achievement in protecting the environment by reducing pollution exposure and carbon dioxide 
emissions as well as reducing mortality ratio linked to diseases appear is seen quite recently. Meanwhile, economic growth tends to be associated with smaller achievement in the enrolment ratio at pre-primary education level and subscriptions to fixed broadband whereas its association with poverty reduction and increasing women power in national parliament seems to flatten over time.

This paper suggests that mobilizing tax revenue collection and government expenditure as well as enhancing governance quality such as improving political freedom and government effectiveness is associated with higher economic growth and better sustainable development outcomes. Under the current circumstance, the Covid-19 pandemic has negatively and tremendously affected economic performance, the foundations of sustainable development have been weakened such as decreasing school attendance, increasing poverty as well as income inequality, etc. It highlights the crucial need for a sound fiscal policy to boost economic and inclusive growth. Our findings make it all the more imperative for governments to strengthen tax revenues to safeguard fiscal sustainability. Unsustainable fiscal policy that results in high public debt to GDP ratios can jeopardize economic growth. ${ }^{3}$ This also emphasizes one of the potential extensions of our research which is to consider the fiscal distributional impacts, i.e., government expenditure allocation and tax revenue contribution, on inclusive growth.

\footnotetext{
${ }^{3}$ See, for example, Salmon and de Rugy (2020) for the literature review on the debt-growth relationship.
} 


\section{KEY TAKEAWAYS}

1. Fiscal stimuli in the previous year are associated with a $1.8 \%$ increase in gross domestic product (GDP) growth rate in the current period. However, the association between fiscal consolidation and economic growth is not statistically significant. On the reversed direction, increasing GDP growth lowers the demand for fiscal stimuli. In particular, a 1\% increase in lagged GDP growth compared to its previous year is associated with a $0.6 \%$ decrease in the chance of having fiscal stimuli next year.

2. Increasing GDP in the previous year is associated with sustainable development in the current period: lower poverty headline ratio, lower undernourished population ratio, lower mortality rate due to cardiovascular disease, cancer, diabetes, or chronic respiratory disease, lower non-educated youth population ratio, lower $\mathrm{PM}_{2.5}$ air pollution, lower carbon dioxide damage in gross national income, lower displacement cases due to disasters, lower percentage of firms experiencing bribery, higher enrolment ratio at pre-primary school, higher women shares in national parliaments, higher population ratio having access to basic sanitation services as well as clean fuels and technologies for cooking, higher broadband subscription rate, higher consumption for bottom $40 \%$ population, larger marine and terrestrial protected areas, and higher remittances in GDP. The findings remain under the scenario of limited GDP resource allocation.

3. Fiscal policy (higher tax revenue and expenses) and political quality (more political rights freedom and higher government effectiveness) are positively associated with higher GDP, which in turn is positively associated with better sustainable development outcomes.

4. As GDP grows, high-income, high-tax-revenue, and manufacture-exporting economies have achieved better goals related to mortality reduction and environmental protection. Nonetheless, emerging and developing, low-tax-revenue, and commodity-exporting economies have made progress on primary goals such as poverty reduction, pre-primary enrolment enhancement, improvement in access to basic sanitation services, and clean cooking fuels and technologies, and reduction in bribery incidence in public transactions. No significant differences are found for highdebt versus low-debt economies.

5. Historically, the sampled countries have consistently enhanced access to primary necessities such as basic sanitation services and clean fuels and technologies for cooking. The reduction in disease-linked mortality ratio and improvement in environmental protection can be seen more recently. Other development goals such as school enrolment at pre-primary education level and fixed broadband subscriptions show less improvement as GDP grows, which are not surprising.

\section{HIGHLIGHTS}

This panel data analysis shed insightful light on the role of fiscal stimuli episodes to economic growth as well as the role of tax revenue, primary expenses, and political quality to GDP and in turn sustainable development outcomes.

Large fiscal expansion episodes are positively associated with economic growth and increasing GDP is associated with better sustainable development indicators. In addition, improving governance quality is also positively associated with GDP. Our study emphasizes the need to mobilize tax revenue and efficiently allocate government expenditure with priorities as a part of fiscal expansion strategy to boost inclusive growth and achieve sustainable development goals. 


\section{TABLES}

Table 1. Fiscal episodes impact on economic growth

Fiscal stimuli this year are positively associated with GDP growth in the next year but not fiscal consolidation episodes. Next, is higher GDP growth associated with lower probability of fiscal expansion?

\begin{tabular}{lcccc}
\hline & $(1)$ & $(2)$ & $(3)$ & $(4)$ \\
& $\Delta$ GDP growth $_{\mathrm{t}}$ & $\Delta$ GDP growth $_{\mathrm{t}}$ & $\Delta$ GDP growth $_{\mathrm{t}}$ & $\Delta$ GDP growth $_{\mathrm{t}}$ \\
\hline Fiscal stimulit-1 & $1.802^{* * *}$ & & 0.523 & \\
& $(0.509)$ & & $(0.522)$ & \\
Fiscal consolidation & & & & 0.078 \\
& & -0.021 & & $(0.375)$ \\
Observations & & $(0.381)$ & 1390 & 1390 \\
Year dummies & 1390 & 1390 & Yes & Yes \\
p-value & No & No & 0.000 & 0.000 \\
$\mathrm{R}^{2}$ (within) & 0.001 & 0.956 & 0.304 & 0.303 \\
\hline
\end{tabular}

$\mathrm{GDP}=$ gross domestic product.

Note: Fixed-effects regressions results for equation (3). Robust standard errors in parentheses. $*, * *, * * *$ significant at $10 \%, 5 \%$, and $1 \%$ respectively.

Table 2. Economic growth impact on fiscal episodes

Better GDP growth this year is negatively associated with probability of fiscal stimuli episodes in the next year. No correlation is found for fiscal consolidation. Next, what is the association between GDP and sustainable development outcomes?

\begin{tabular}{|c|c|c|c|c|}
\hline & \multicolumn{2}{|c|}{ Probit } & \multicolumn{2}{|c|}{ Logit } \\
\hline & (1) & $(2)$ & (3) & (4) \\
\hline & Fiscal stimuli $\mathrm{t}_{\mathrm{t}}$ & $\begin{array}{c}\text { Fiscal } \\
\text { consolidation }_{\mathrm{t}}\end{array}$ & Fiscal stimuli ${ }_{t}$ & $\begin{array}{c}\text { Fiscal } \\
\text { consolidation }_{\mathrm{t}}\end{array}$ \\
\hline \multirow[t]{2}{*}{$\Delta \mathrm{GDP}$ growth $\mathrm{t}_{\mathrm{t}-1}$} & $-0.031 * * *$ & -0.009 & $-0.058 * * *$ & -0.016 \\
\hline & $(0.010)$ & (0.013) & $(0.019)$ & $(0.026)$ \\
\hline Observations & 1378 & 1378 & 1378 & 1378 \\
\hline$p$-value & 0.003 & 0.458 & 0.003 & 0.548 \\
\hline Log-likelihood & -512.253 & -462.855 & -512.226 & -463.424 \\
\hline Pseudo- $R^{2}$ & 0.018 & 0.022 & 0.018 & 0.021 \\
\hline
\end{tabular}

$\mathrm{GDP}=$ gross domestic product.

Note: Estimation results for equation (4) by probit regression with random effects in columns (1)-(2) and by logit regression with random effects in columns (3)-(4). Robust standard errors in parentheses. ${ }^{*}, * *, * * *$ significant at $10 \%, 5 \%$, and $1 \%$ respectively. 
Table 3. Economic growth and sustainable development

Higher GDP in the last year is positively associated with better sustainable development outcomes in the current period. Next, what if GDP resource is limited?

\begin{tabular}{|c|c|c|c|c|c|c|c|c|c|}
\hline & $\begin{array}{c}\text { (1) } \\
\text { Poverty }\end{array}$ & $\begin{array}{c}(2) \\
\text { Undernourishment } t_{t}\end{array}$ & $\begin{array}{c}\text { (3) } \\
\text { Mortality }\end{array}$ & $\begin{array}{c}\text { (4) } \\
\text { Enrollment }_{t}\end{array}$ & $\begin{array}{c}\text { (5) } \\
\text { Women power } \\
\text { Wo }\end{array}$ & $\begin{array}{c}(6) \\
\text { Sanitation }_{\mathrm{t}}\end{array}$ & $\begin{array}{c}(7) \\
\text { Fuel-Tech }\end{array}$ & $\begin{array}{c}(8) \\
\text { Non-education }_{t}\end{array}$ & $\begin{array}{c}\text { (9) } \\
\text { Broadband }\end{array}$ \\
\hline $\mathrm{GDP}_{\mathrm{t}-1}$ & $\begin{array}{c}-0.976 * * * \\
(0.235)\end{array}$ & $\begin{array}{c}-0.428^{* * *} \\
(0.120)\end{array}$ & $\begin{array}{c}-0.452 * * * \\
(0.057)\end{array}$ & $\begin{array}{c}0.435 * * * \\
(0.079)\end{array}$ & $\begin{array}{c}0.829 * * * \\
(0.066)\end{array}$ & $\begin{array}{c}0.111 * * * \\
(0.027)\end{array}$ & $\begin{array}{c}0.296 * * * \\
(0.059)\end{array}$ & $\begin{array}{c}-0.363^{* * *} \\
(0.081)\end{array}$ & $\begin{array}{c}6.667 * * * \\
(0.841)\end{array}$ \\
\hline $\begin{array}{l}\text { Observations } \\
p \text {-value } \\
R^{2} \text { (within) }\end{array}$ & $\begin{array}{c}651 \\
0.000 \\
0.223\end{array}$ & $\begin{array}{l}1174 \\
0.001 \\
0.193\end{array}$ & $\begin{array}{l}1216 \\
0.000 \\
0.449\end{array}$ & $\begin{array}{l}1362 \\
0.000 \\
0.351\end{array}$ & $\begin{array}{l}1343 \\
0.000 \\
0.323\end{array}$ & $\begin{array}{l}1250 \\
0.000 \\
0.257\end{array}$ & $\begin{array}{l}1029 \\
0.000 \\
0.345\end{array}$ & $\begin{array}{c}903 \\
0.000 \\
0.108\end{array}$ & $\begin{array}{l}1196 \\
0.000 \\
0.538\end{array}$ \\
\hline
\end{tabular}

(cont.)

$(10)$

(11)

(12)

(13)

(14)

(15)

(16)

(17)

Bottom consumption $_{\mathrm{t}} \quad$ Pollution $_{\mathrm{t}}$

Carbon dioxide

Displacement $_{\mathrm{t}}$ Marine $_{\mathrm{t}}$ Terrestrial $_{\mathrm{t}}$ Bribery $_{\mathrm{t}}$ Remittances $_{\mathrm{t}}$

\begin{tabular}{lcccccccc}
\hline GDP -1 & $0.911^{* * *}$ & $-0.181^{* * *}$ & $-0.506^{* * *}$ & -1.542 & $1.788^{* *}$ & $0.505^{* *}$ & $-1.551^{* * *}$ & $1.152^{* * *}$ \\
& $(0.139)$ & $(0.016)$ & $(0.093)$ & $(1.180)$ & $(0.846)$ & $(0.246)$ & $(0.515)$ & $(0.347)$ \\
& & & & & & & \\
& & 1358 & 1498 & 481 & 152 & 188 & 331 \\
Observations & 301 & 0.000 & 0.000 & 0.196 & 0.040 & 0.044 & 0.004 & 0.001 \\
p-value & 0.000 & 0.280 & 0.212 & 0.008 & 0.024 & 0.046 & 0.157 & 0.107 \\
$\mathrm{R}^{2}$ (within) & 0.495 & & &
\end{tabular}

GDP $=$ gross domestic product.

Note: Fixed-effects regressions results for equation (5) excluding year dummies. All sustainable development goals and gross domestic product are in natural logarithm. Robust standard errors in parentheses. ${ }^{*}, * * * * *$ significant at $10 \%, 5 \%$, and $1 \%$ respectively. 
Table 4. Economic growth and sustainable development under limited resource scenario

GDP is still positively associated with most of the sustainable development outcomes. Next, any linkages between GDP, sustainable development outcomes, and fiscal policy?

\begin{tabular}{|c|c|c|c|c|c|c|}
\hline & $\begin{array}{c}(1) \\
\text { Undernourishment }\end{array}$ & $\begin{array}{c}(2) \\
\text { Mortality }\end{array}$ & $\begin{array}{c}\text { (3) } \\
\text { Enrollment }\end{array}$ & $\begin{array}{c}\text { (4) } \\
\text { Women power }\end{array}$ & $\begin{array}{c}(5) \\
\text { Sanitation }_{t}\end{array}$ & $\begin{array}{c}\text { (6) } \\
\text { Fuel-Tech, }\end{array}$ \\
\hline $\mathrm{GDP}_{\mathrm{t}-1}$ & $\begin{array}{c}-0.599 * * \\
(-2.80)\end{array}$ & $\begin{array}{c}-0.390 * * * \\
(-4.47)\end{array}$ & $\begin{array}{c}0.369 * * * \\
(5.67)\end{array}$ & $\begin{array}{c}0.542 * * * \\
(4.89)\end{array}$ & $\begin{array}{c}0.120 * * * \\
(4.43)\end{array}$ & $\begin{array}{c}0.237^{* * *} \\
(3.42)\end{array}$ \\
\hline Observations & 628 & 628 & 628 & 628 & 628 & 628 \\
\hline p-value & 0.000 & 0.000 & 0.000 & 0.000 & 0.000 & 0.000 \\
\hline $\mathrm{R}^{2}$ & 0.942 & 0.955 & 0.950 & 0.863 & 0.974 & 0.953 \\
\hline
\end{tabular}

(cont.)

\begin{tabular}{|c|c|c|c|c|c|}
\hline & $\begin{array}{c}\text { (7) } \\
\text { Non-education }_{t}\end{array}$ & $\begin{array}{c}\text { (8) } \\
\text { Broadband }_{t}\end{array}$ & $\begin{array}{c}\text { (9) } \\
\text { Pollution }\end{array}$ & $\begin{array}{c}(10) \\
\text { Carbon dioxide } \\
\text { damage }_{t}\end{array}$ & $\begin{array}{c}\text { (11) } \\
\text { Remittances } t\end{array}$ \\
\hline $\mathrm{GDP}_{\mathrm{t}-1}$ & $\begin{array}{c}-0.267 * * * \\
(-3.36)\end{array}$ & $\begin{array}{c}5.996 * * * \\
(11.40)\end{array}$ & $\begin{array}{c}-0.303^{* * *} \\
(-10.21)\end{array}$ & $\begin{array}{c}-0.668 * * * \\
(-5.69)\end{array}$ & $\begin{array}{l}0.666 \\
(1.34)\end{array}$ \\
\hline Observations & 628 & 628 & 628 & 628 & 628 \\
\hline$p$-value & 0.000 & 0.000 & 0.000 & 0.000 & 0.000 \\
\hline R-squared & 0.914 & 0.863 & 0.980 & 0.963 & 0.910 \\
\hline
\end{tabular}

GDP $=$ gross domestic product.

Note: Seemingly unrelated regression (SUR) results for equation (5), including country dummies and cluster by country. Number of observations is dropped dramatically due to the strongly balanced panel data required by SUR. All sustainable development goals and gross domestic product are in natural logarithm. Robust standard errors in parentheses. ${ }^{*}, * * * *$ significant at $10 \%, 5 \%$, and $1 \%$ respectively. 
Table 5. Sustainable development, economic growth, tax revenue, and political rights

Higher total tax revenue and more political freedom are positively associated with higher GDP, which in turn is positively associated with better sustainable development outcomes. Next, how about primary expenses?

\begin{tabular}{|c|c|c|c|c|c|c|c|c|c|}
\hline & $\begin{array}{c}\text { (1) } \\
\text { Povertyt }\end{array}$ & $\begin{array}{c}\text { (2) } \\
\text { Undernourishment } t_{t}\end{array}$ & $\begin{array}{c}\text { (3) } \\
\text { Mortalityt }\end{array}$ & $\begin{array}{c}\text { (4) } \\
\text { Enrollment }\end{array}$ & $\begin{array}{c}\text { (5) } \\
\text { Women } \\
\text { power }_{t}\end{array}$ & $\begin{array}{c}\text { (6) } \\
\text { Sanitation }_{\mathrm{t}}\end{array}$ & $\begin{array}{c}\text { (7) } \\
\text { Fuel-Techt }\end{array}$ & $\begin{array}{c}\text { (8) } \\
\text { Non-education }_{t}\end{array}$ & $\begin{array}{c}\text { (9) } \\
\text { Broadband }\end{array}$ \\
\hline \multicolumn{10}{|c|}{ First-stage: Dependent variable $=\mathrm{GDP}_{\mathrm{t}-1}$} \\
\hline Tax revenue $\mathrm{t}_{-2}$ & $\begin{array}{c}0.276 * * * \\
(15.57)\end{array}$ & $\begin{array}{c}0.333 * * * \\
(27.85)\end{array}$ & $\begin{array}{c}0.335 * * * \\
(29.94)\end{array}$ & $\begin{array}{c}0.288 * * * \\
(16.38)\end{array}$ & $\begin{array}{c}0.305 * * * \\
(16.51)\end{array}$ & $\begin{array}{c}0.339 * * * \\
(30.77)\end{array}$ & $\begin{array}{c}0.330 * * * \\
(29.60)\end{array}$ & $\begin{array}{c}0.375 * * * \\
(41.21)\end{array}$ & $\begin{array}{c}0.344 * * * \\
(28.36)\end{array}$ \\
\hline Political rights $\mathrm{t}_{-2}$ & $\begin{array}{c}0.108^{*} \\
(2.48)\end{array}$ & $\begin{array}{c}0.0445 \\
(1.70)\end{array}$ & $\begin{array}{c}0.0579 * \\
(2.16)\end{array}$ & $\begin{array}{c}0.0196 \\
(0.54)\end{array}$ & $\begin{array}{c}0.0364 \\
(0.99)\end{array}$ & $\begin{array}{c}0.0597^{*} \\
(2.24)\end{array}$ & $\begin{array}{c}0.0770^{*} \\
(2.55)\end{array}$ & $\begin{array}{c}0.101 * * * \\
(3.80)\end{array}$ & $\begin{array}{c}0.0552^{*} \\
(2.13)\end{array}$ \\
\hline F-statistic & 121.170 & 432.526 & 488.328 & 157.627 & 188.412 & 517.067 & 448.565 & 860.540 & 438.454 \\
\hline$p$-value & 0.000 & 0.000 & 0.000 & 0.000 & 0.000 & 0.000 & 0.000 & 0.000 & 0.000 \\
\hline \multicolumn{10}{|c|}{ Second-stage: Dependent variable $=$ SDGs } \\
\hline $\mathrm{GDP}_{\mathrm{t}-1}$ & $\begin{array}{c}-1.344 * * * \\
(0.281)\end{array}$ & $\begin{array}{c}-0.377^{* * *} \\
(0.050)\end{array}$ & $\begin{array}{c}-0.535 * * * \\
(0.030)\end{array}$ & $\begin{array}{c}0.587^{* * *} \\
(0.032)\end{array}$ & $\begin{array}{c}0.899 * * * \\
(0.049)\end{array}$ & $\begin{array}{c}0.131 * * * \\
(0.009)\end{array}$ & $\begin{array}{c}0.298 * * * \\
(0.023)\end{array}$ & $\begin{array}{c}-0.231 * * * \\
(0.044)\end{array}$ & $\begin{array}{c}8.104^{* * *} \\
(0.319)\end{array}$ \\
\hline \multicolumn{10}{|c|}{ Overidentification test } \\
\hline Chi-squared & 0.005 & 0.290 & 0.174 & 9.920 & 0.193 & 6.621 & 1.140 & 0.209 & 2.581 \\
\hline $\begin{array}{l}\mathrm{p} \text {-value } \\
\text { Endogeneity test }\end{array}$ & 0.945 & 0.590 & 0.676 & 0.002 & 0.660 & 0.010 & 0.286 & 0.648 & 0.108 \\
\hline Chi-squared & 7.502 & 0.222 & 19.047 & 19.281 & 21.310 & 32.576 & 24.547 & 26.396 & 39.362 \\
\hline$p$-value & 0.006 & 0.638 & 0.000 & 0.000 & 0.000 & 0.000 & 0.000 & 0.000 & 0.000 \\
\hline Observations & 612 & 1063 & 1134 & 1141 & 1252 & 1130 & 950 & 849 & 1097 \\
\hline$p$-value & 0.000 & 0.000 & 0.000 & 0.000 & 0.000 & 0.000 & 0.000 & 0.000 & 0.000 \\
\hline
\end{tabular}


(cont.)

(10)

Bottom consumption $_{\mathrm{t}}$

(12)

(13)

(14)

(15)

(16)

(17)

Pollution $_{t}$

Carbon dioxide damage $e_{t}$

Displacement $t$

Marine $_{\mathrm{t}}$ Terrestrial $_{\mathrm{t}}$

Bribery $t$

Remittancest

\begin{tabular}{|c|c|c|c|c|c|c|c|c|}
\hline \multicolumn{9}{|c|}{ First-stage: Dependent varlable $=G \mathrm{GP} t-1$} \\
\hline Tax revenue $\mathrm{t}_{-2}$ & $\begin{array}{c}0.392 * * * \\
(9.78)\end{array}$ & $\begin{array}{c}0.278 * * * \\
(16.03)\end{array}$ & $\begin{array}{c}0.289 * * * \\
(17.37)\end{array}$ & $\begin{array}{c}0.350 * * * \\
(12.18)\end{array}$ & $\begin{array}{c}0.330 * * * \\
(6.01)\end{array}$ & $\begin{array}{c}0.338 * * * \\
(6.66)\end{array}$ & $\begin{array}{c}0.254^{* * *} \\
(9.84)\end{array}$ & $\begin{array}{c}0.297 * * * \\
(17.23)\end{array}$ \\
\hline \multirow[t]{2}{*}{ Political rightst-2 } & -0.0441 & 0.0240 & 0.00317 & 0.0304 & -0.00309 & -0.0170 & $-0.0676^{*}$ & 0.0243 \\
\hline & $(-1.64)$ & $(0.66)$ & $(0.09)$ & $(0.65)$ & $(-0.08)$ & $(-0.39)$ & $(-2.40)$ & $(0.70)$ \\
\hline F-statistics & 76.767 & 146.869 & 187.826 & 78.743 & 18.282 & 22.193 & 67.160 & 179.445 \\
\hline p-value & 0.000 & 0.000 & 0.000 & 0.000 & 0.000 & 0.000 & 0.000 & 0.000 \\
\hline \multicolumn{9}{|c|}{ Second-stage: Dependent variable $=S$ SDG $_{t}$} \\
\hline \multirow[t]{2}{*}{$\mathrm{GDP}_{\mathrm{t}-1}$} & $1.069 * * *$ & $-0.237 * * *$ & $-0.587 * * *$ & $-3.069 * *$ & $5.231 * *$ & 0.332 & $-1.939 * * *$ & $1.968 * * *$ \\
\hline & $(0.104)$ & $(0.014)$ & $(0.065)$ & $(1.375)$ & $(2.177)$ & $(0.265)$ & $(0.298)$ & $(0.181)$ \\
\hline \multicolumn{9}{|c|}{ Overidentification test } \\
\hline Chi-squared & 0.268 & 8.906 & 0.560 & 0.008 & 1.268 & 1.419 & 4.216 & 12.841 \\
\hline$p$-value & 0.605 & 0.003 & 0.454 & 0.927 & 0.260 & 0.234 & 0.040 & 0.000 \\
\hline \multicolumn{9}{|l|}{ Endogeneity test } \\
\hline Chi-squared & 6.239 & 7.621 & 0.381 & 2.946 & 3.212 & 0.859 & 9.789 & 11.231 \\
\hline$p$-value & 0.012 & 0.006 & 0.537 & 0.086 & 0.073 & 0.354 & 0.002 & 0.001 \\
\hline Observations & 300 & 1168 & 1271 & 461 & 150 & 184 & 308 & 1260 \\
\hline$p$-value & 0.000 & 0.000 & 0.000 & 0.026 & 0.019 & 0.215 & 0.000 & 0.000 \\
\hline
\end{tabular}

GDP = gross domestic product; SDGs = sustainable development goals.

Note: 1. Two-stage least squares regression results for equation (5) whereas in the first stage, gross domestic product is regressed on total tax revenue and political rights. Total tax revenue is computed from Total tax revenue (\% of GDP) and nominal GDP. All sustainable development goals, gross domestic product, and total tax revenue are in natural logarithm. Robust standard errors in parentheses. ${ }^{*}, * * * * *$ significant at $10 \%, 5 \%$, and $1 \%$ respectively.

2. First-stage test is under the null hypothesis that the coefficients of the excluded instruments are jointly equal to zero. Overidentification test is under the joint null hypothesis that the instruments are valid, i.e., uncorrelated with the error term, and that the excluded instruments are correctly excluded from the estimated equation. Endogeneity test is under the null hypothesis that the specified endogenous regressors can be treated as exogenous. 
Table 6. Sustainable development, economic growth, primary expenses, and political rights

Higher primary expenses and more political freedom are also positively associated with higher GDP, which in turn is positively associated with better sustainable development outcomes.

\begin{tabular}{|c|c|c|c|c|c|c|c|c|c|}
\hline & (1) & $(2)$ & (3) & (4) & (5) & (6) & (7) & (8) & (9) \\
\hline & Poverty & Undernourishment $t_{t}$ & Mortalityt & Enrollment $t_{t}$ & $\begin{array}{l}\text { Women } \\
\text { powert }_{\mathrm{t}}\end{array}$ & Sanitation $_{\mathrm{t}}$ & Fuel-Techt & Non-education $_{\mathrm{t}}$ & Broadband $_{\mathrm{t}}$ \\
\hline \multicolumn{10}{|c|}{ First-stage: Dependent variable $=\mathrm{GDP}_{\mathrm{t}-1}$} \\
\hline Primary expensest-2 & $\begin{array}{c}0.260 * * * \\
(16.03)\end{array}$ & $\begin{array}{c}0.316 * * * \\
(28.14)\end{array}$ & $\begin{array}{c}0.318 * * * \\
(30.49)\end{array}$ & $\begin{array}{c}0.272 * * * \\
(17.16)\end{array}$ & $\begin{array}{c}0.291^{* * *} \\
(16.90)\end{array}$ & $\begin{array}{c}0.321 * * * \\
(31.25)\end{array}$ & $\begin{array}{c}0.308 * * * \\
(30.41)\end{array}$ & $\begin{array}{c}0.356 * * * \\
(40.18)\end{array}$ & $\begin{array}{c}0.322 * * * \\
(29.14)\end{array}$ \\
\hline Political rights $\mathrm{s}_{\mathrm{t}-2}$ & $\begin{array}{c}0.123^{*} \\
(2.51)\end{array}$ & $\begin{array}{c}0.0584 \\
(1.83)\end{array}$ & $\begin{array}{c}0.0710^{*} \\
(2.23)\end{array}$ & $\begin{array}{c}0.0292 \\
(0.77)\end{array}$ & $\begin{array}{c}0.0445 \\
(1.15)\end{array}$ & $\begin{array}{c}0.0729 * \\
(2.30)\end{array}$ & $\begin{array}{c}0.0924^{*} \\
(2.53)\end{array}$ & $\begin{array}{c}0.0956 * * \\
(2.85)\end{array}$ & $\begin{array}{c}0.0664^{*} \\
(2.11)\end{array}$ \\
\hline F-statistic & 128.449 & 431.539 & 498.165 & 169.525 & 188.945 & 523.942 & 474.226 & 820.719 & 452.622 \\
\hline$p$-value & 0.000 & 0.000 & 0.000 & 0.000 & 0.000 & 0.000 & 0.000 & 0.000 & 0.000 \\
\hline \multicolumn{10}{|c|}{ Second-stage: Dependent variable = SDGs } \\
\hline $\mathrm{GDP}_{\mathrm{t}-1}$ & $\begin{array}{c}-1.325^{* * *} \\
(0.283)\end{array}$ & $\begin{array}{c}-0.377^{* * *} \\
(0.050)\end{array}$ & $\begin{array}{c}-0.574 * * * \\
(0.033)\end{array}$ & $\begin{array}{c}0.599 * * * \\
(0.032)\end{array}$ & $\begin{array}{c}0.940 * * * \\
(0.050)\end{array}$ & $\begin{array}{c}0.125^{* * *} \\
(0.009)\end{array}$ & $\begin{array}{c}0.297 * * * \\
(0.025)\end{array}$ & $\begin{array}{c}-0.148 * * * \\
(0.044)\end{array}$ & $\begin{array}{c}8.378 * * * \\
(0.325)\end{array}$ \\
\hline \multicolumn{10}{|c|}{ Overidentification test } \\
\hline Chi-squared & 0.003 & 0.286 & 0.036 & 9.789 & 0.187 & 7.225 & 1.146 & 0.434 & 2.257 \\
\hline \multicolumn{10}{|l|}{ Endogeneity test } \\
\hline Chi-squared & 6.991 & 0.173 & 42.998 & 23.979 & 32.775 & 20.691 & 11.586 & 55.139 & 57.265 \\
\hline$p$-value & 0.008 & 0.677 & 0.000 & 0.000 & 0.000 & 0.000 & 0.001 & 0.000 & 0.000 \\
\hline Observations & 612 & 1063 & 1134 & 1141 & 1252 & 1130 & 950 & 849 & 1097 \\
\hline$p$-value & 0.000 & 0.000 & 0.000 & 0.000 & 0.000 & 0.000 & 0.000 & 0.001 & 0.000 \\
\hline
\end{tabular}


(cont.)

(10)

(11)

(12)

(13)

(14)

(15)

(16)

(17)

Bottom consumption ${ }_{t}$

Pollution $_{t} \quad$ Carbon dioxide damage $_{t}$ Displacement $t_{t}$

Marine $_{t}$ Terrestrial $t_{t}$

Briberyt

Remittances $t_{t}$

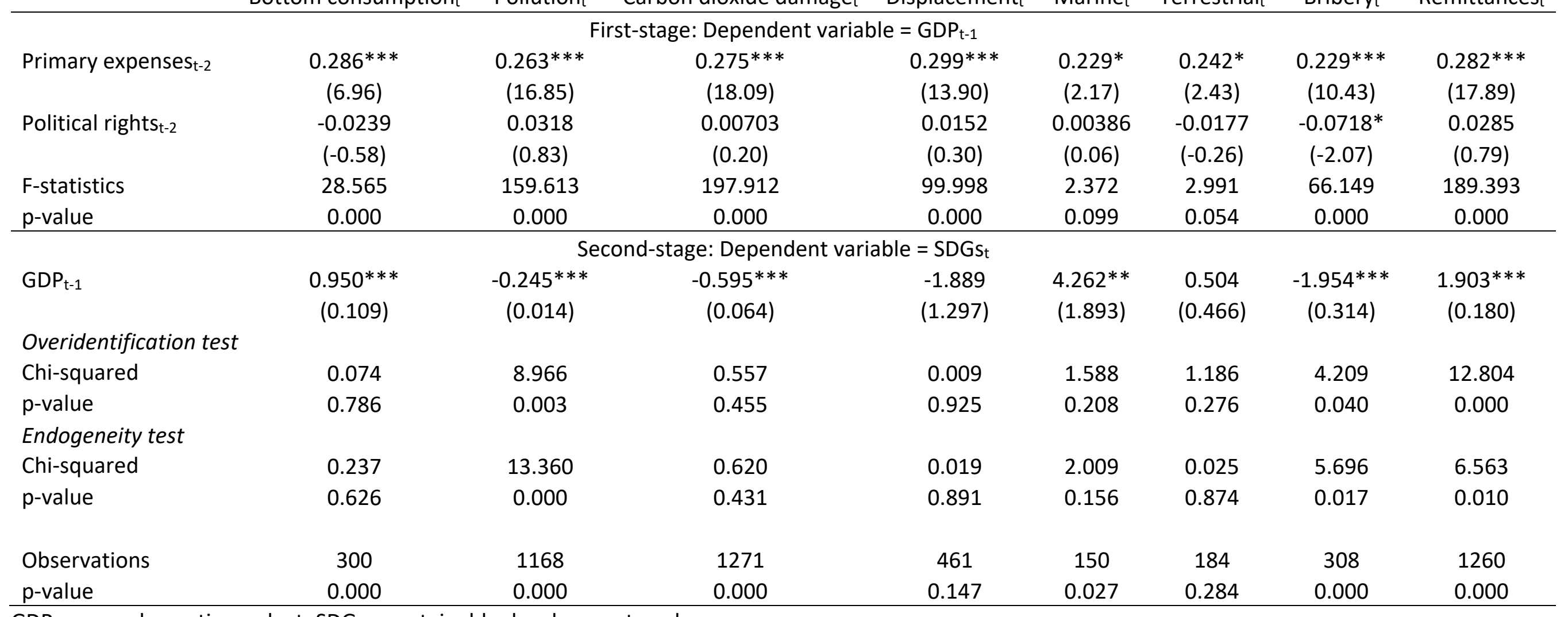

GDP = gross domestic product; SDGs = sustainable development goals.

Note: 1. Two-stage least squares regression results for equation (5) whereas in the first stage, gross domestic product is regressed on primary expenses and political rights. Primary expenses is computed from Primary expenses (\% of GDP) and nominal GDP. All sustainable development goals, gross domestic product, and primary expenses are in natural logarithm. Robust standard errors in parentheses. ${ }^{* * *}, * * *$ significant at $10 \%, 5 \%$, and $1 \%$ respectively.

2. First-stage test is under the null hypothesis that the coefficients of the excluded instruments are jointly equal to zero. Overidentification test is under the joint null hypothesis that the instruments are valid, i.e., uncorrelated with the error term, and that the excluded instruments are correctly excluded from the estimated equation. Endogeneity test is under the null hypothesis that the specified endogenous regressors can be treated as exogenous. 
Figure 1: Sustainable development goals and total tax revenue, 1991-2019

Sustainable development is positively correlated with total tax revenue. How about primary expenses?

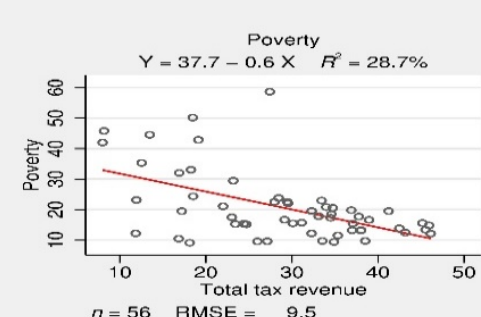

$\begin{array}{ll}\text { Total tax reve } \\ n=56 & \text { RMSE }=9.5\end{array}$

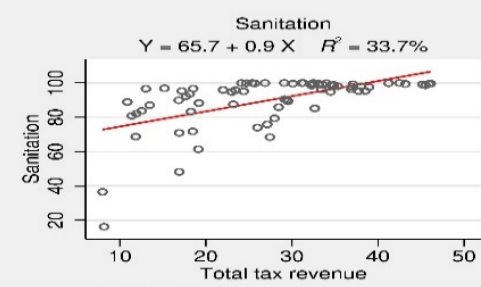

$\begin{array}{cc}10 & 20 \\ \text { Total tax revenue } & 30 \\ n=72 & \operatorname{RMSE}=12.5\end{array}$

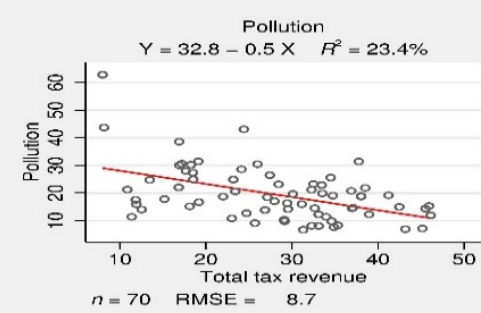

$n=70$ RMSE $=8.7$

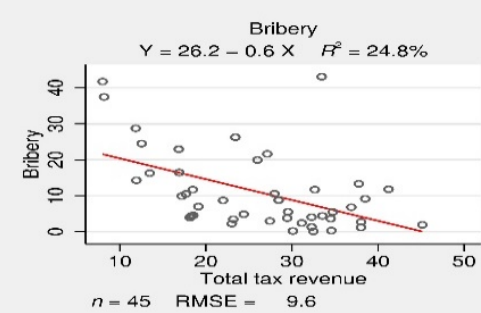

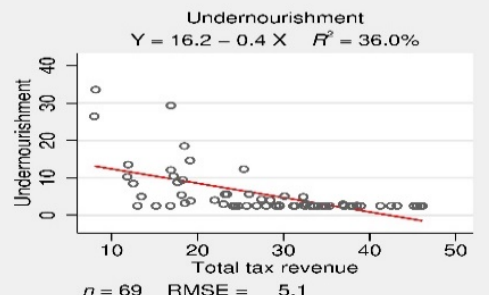

Total tax reven
$n=69$
RMSE $=5.1$

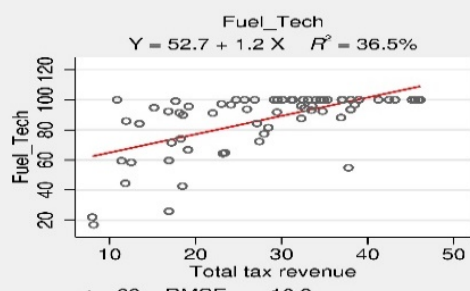

Total tax rev
R
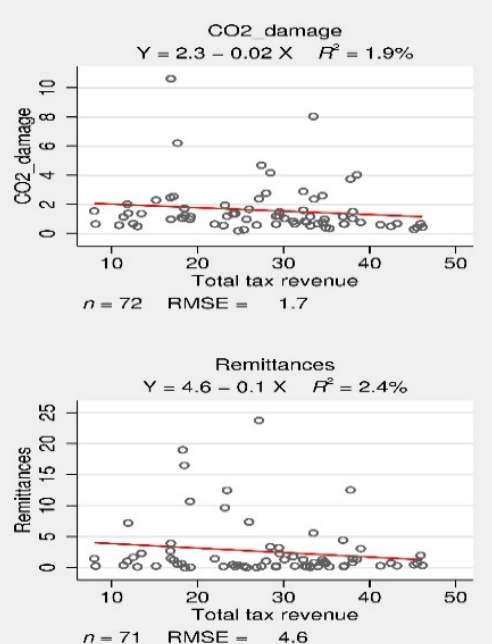
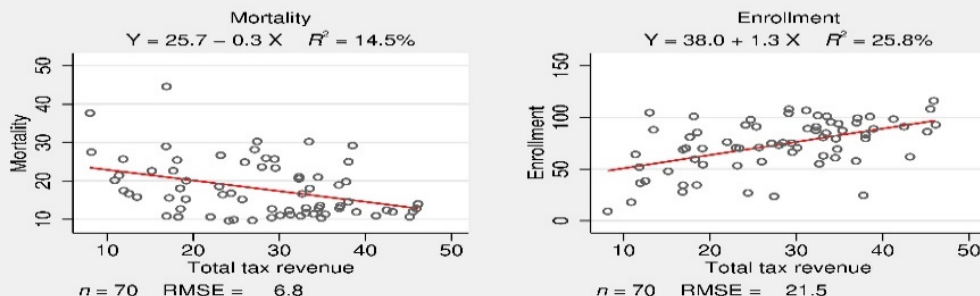

Total tax rever
$n=70 \quad$ RMSE $=21.5$
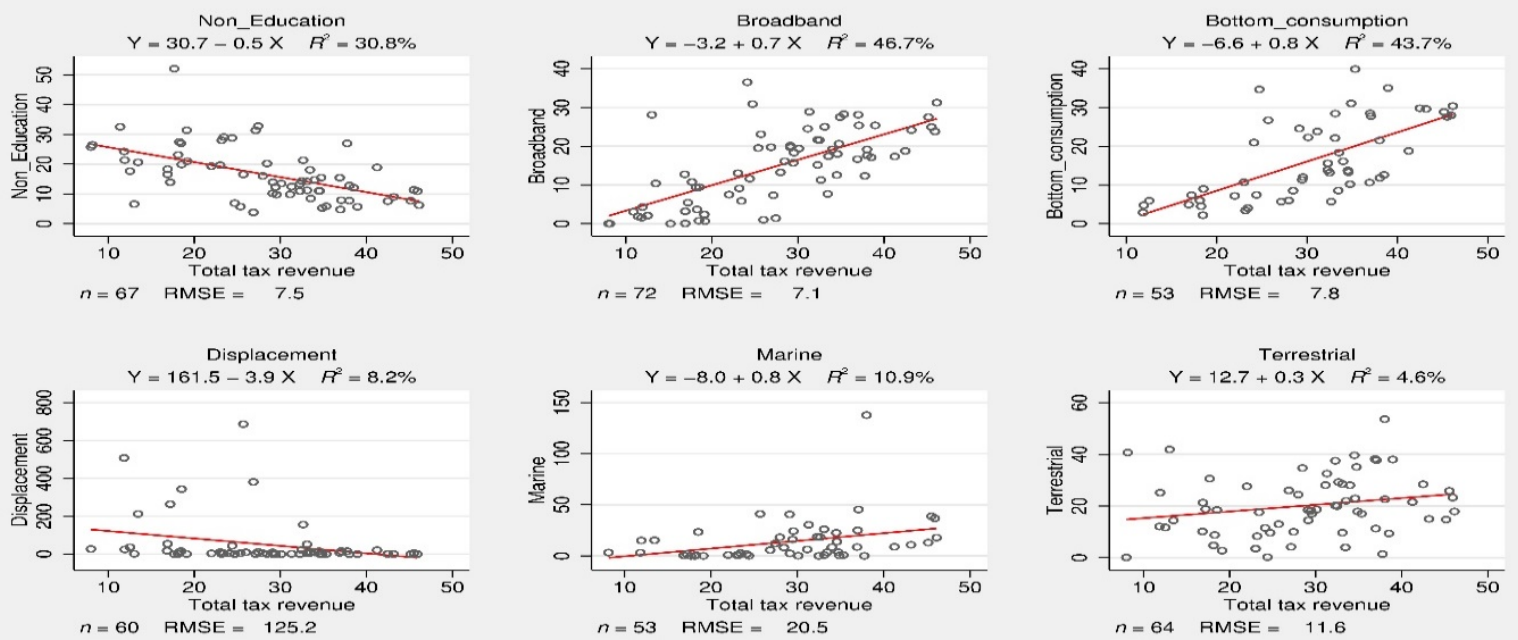

Note: Scatter plots of with linear fit and its statistics including R-square $\left(R^{2}\right)$, number of observations ( $n$ ), and root mean square deviation (RMSD). Countryspecific total tax revenue (\% of GDP) and sustainable development indicators are averaged over the 1991-2019 period. 


\section{Figure 2: Sustainable development goals and primary expenses, 1991-2019}

Sustainable development is positively correlated with primary expenses. Estimation exploiting both tax revenue and primary expenses can shed some light on the relationship between fiscal policy and sustainable development indicators.
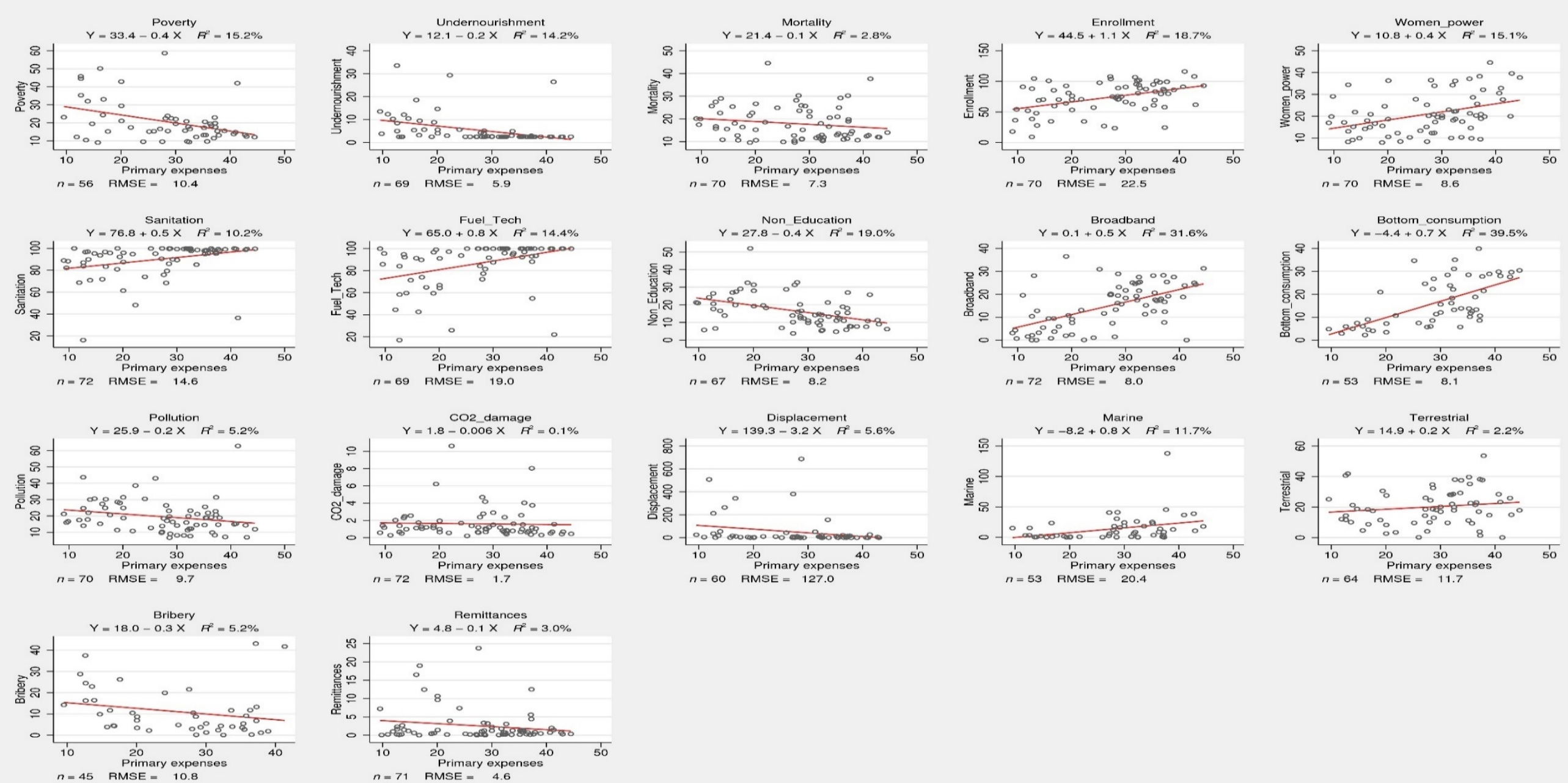

Note: Scatter plot with linear fit and its statistics including R-square $\left(\mathrm{R}^{2}\right)$, number of observations ( $\mathrm{n}$ ), and root mean square deviation (RMSD). Countryspecific primary expenses (\% of GDP) and sustainable development indicators are averaged over the 1991-2019 period. 


\section{Figure 3: Total tax revenue, primary expenses, and political variables, 1991-2019}

Total tax revenue and primary expenses are positively correlated to higher political rights, government effectiveness, and ethnic power relations.
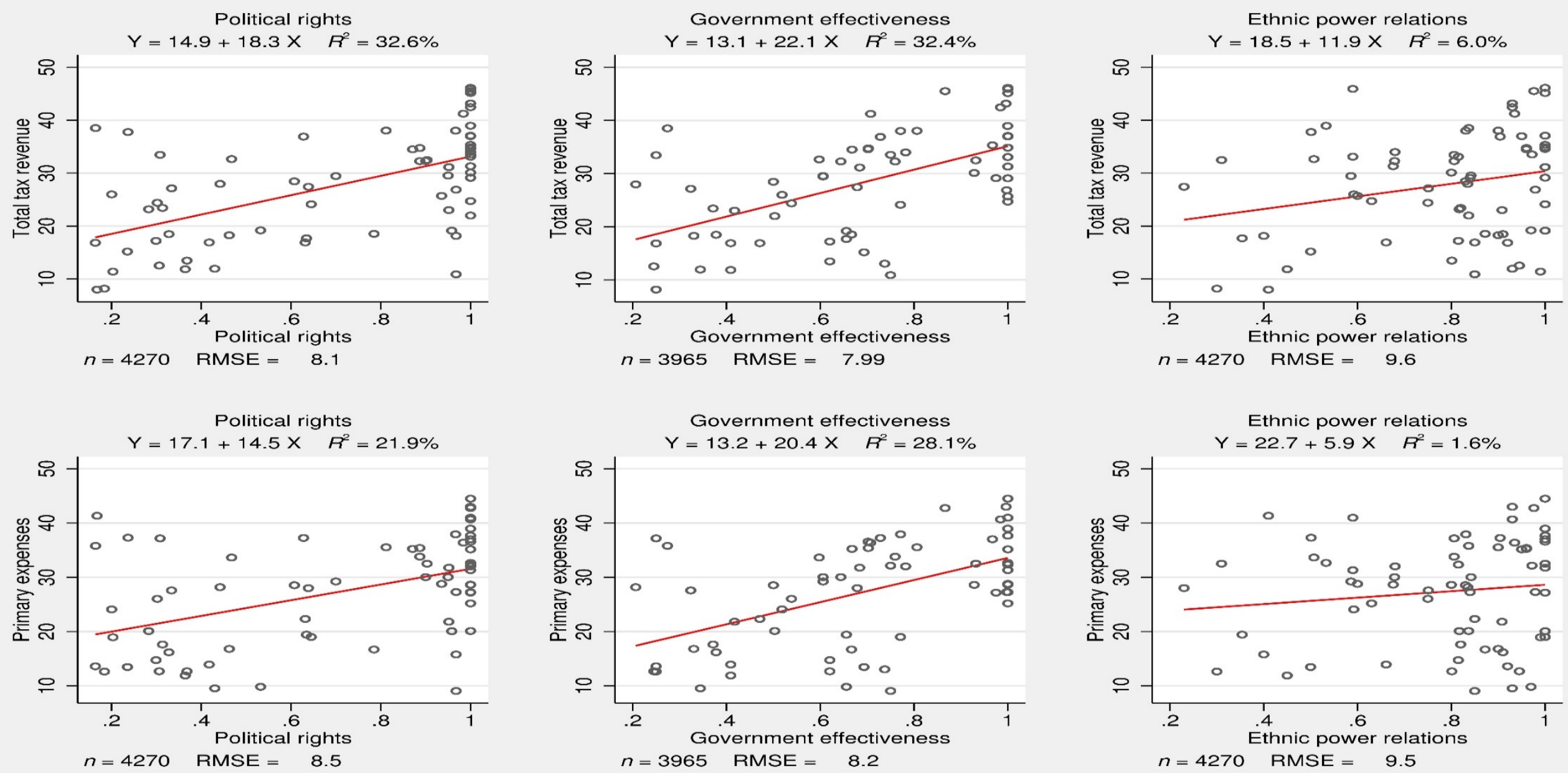

Note: Scatter plot with linear fit and its statistics including R-square $\left(R^{2}\right)$, number of observations ( $n$ ), and root mean square deviation (RMSD). Countryspecific total tax revenue (\% of GDP), primary expenses (\% of GDP), and sustainable development indicators are averaged over the 1991-2019 period. Latest data in year 2021 is used for ethnic power relations. 
Figure 4: Economic growth and fiscal variables by group of economies, 1991-2019

GDP growth appears to be negatively associated with both tax revenue and primary expenses across different groups of economies. Examining the association between GDP growth and fiscal episodes, defined from tax revenue and primary expenses might help explore their relationship.
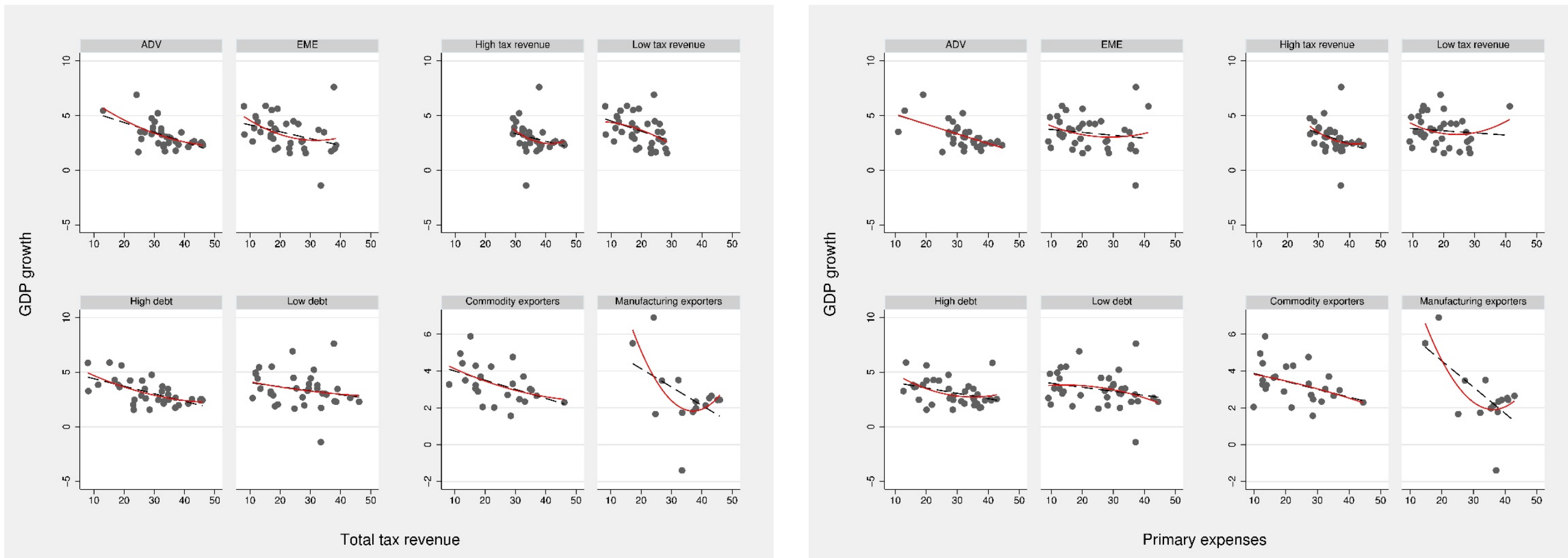

ADV - Advanced economies; EME - Emerging and developing economies.

Note: Scatter plot with linear fit as dash black line and quadratic fit as solid red line by group of economies. Country-specific total tax revenue (\% of GDP), primary expenses (\% of GDP), and GDP growth rate are averaged over 1991-2019 period. 
Figure 5: Fiscal episodes impact on economic growth by group of economies

Fiscal stimuli episodes are positively associated with economic growth with larger impacts on EME, low tax revenue, high debt level, and manufacturing exporters. Fiscal consolidation episodes are mostly not associated with economic growth with only positive association is found in manufacturing exporters.

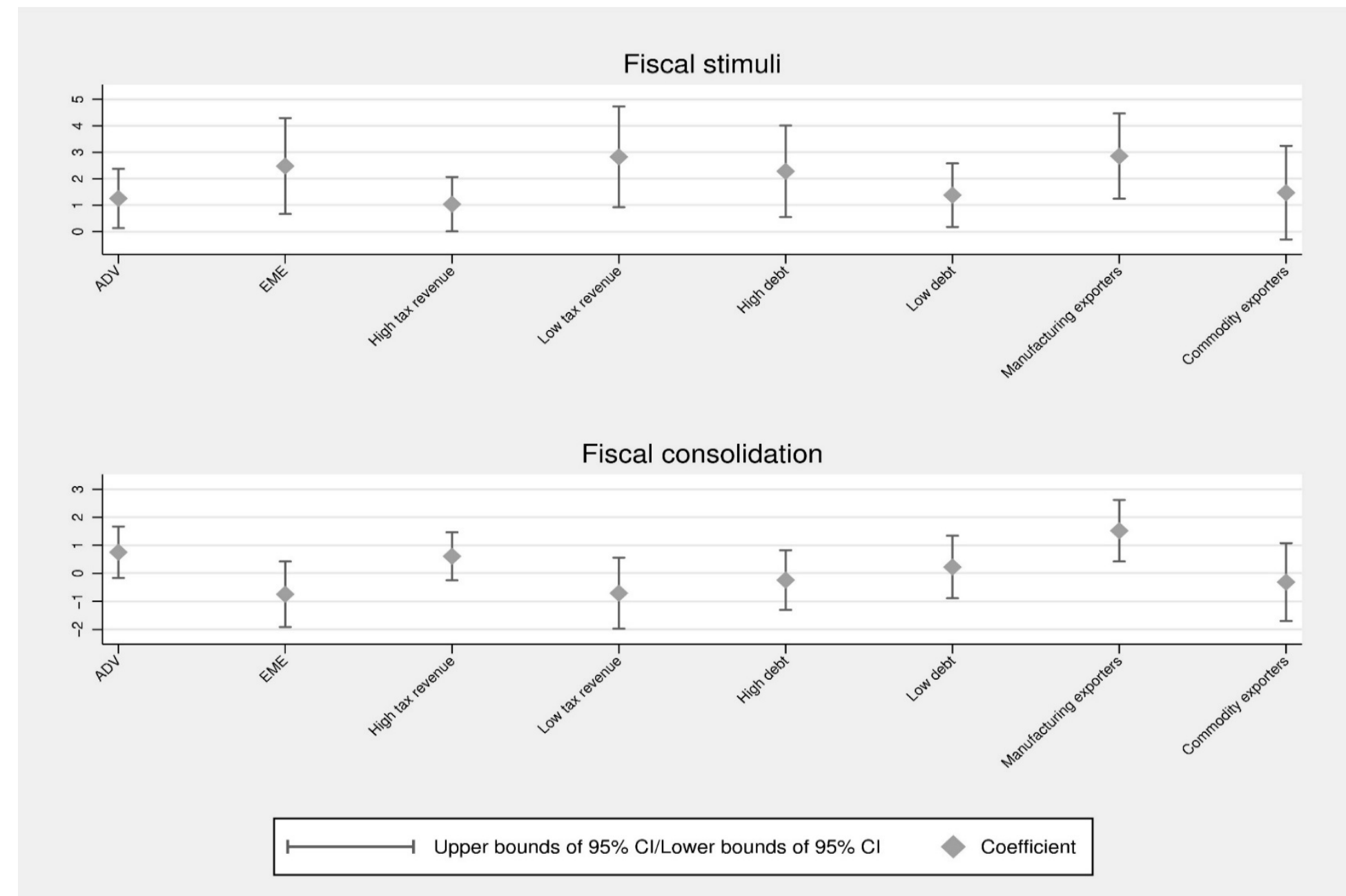

ADV - Advanced economies; EME - Emerging and developing economies; $\mathrm{Cl}$-Confidence intervals.

Note: Fixed-effects regression results from equation (3) excluding year dummies by group of economies. 
Figure 6: Impact of economic growth on poverty by group of economies

Economic growth is negatively associated with poverty headcount ratio in EME and low tax revenue groups but their counterpart economies. Larger impacts are found in low debt economies and manufacturing exporters than in high debt economies and commodity exporters respectively.

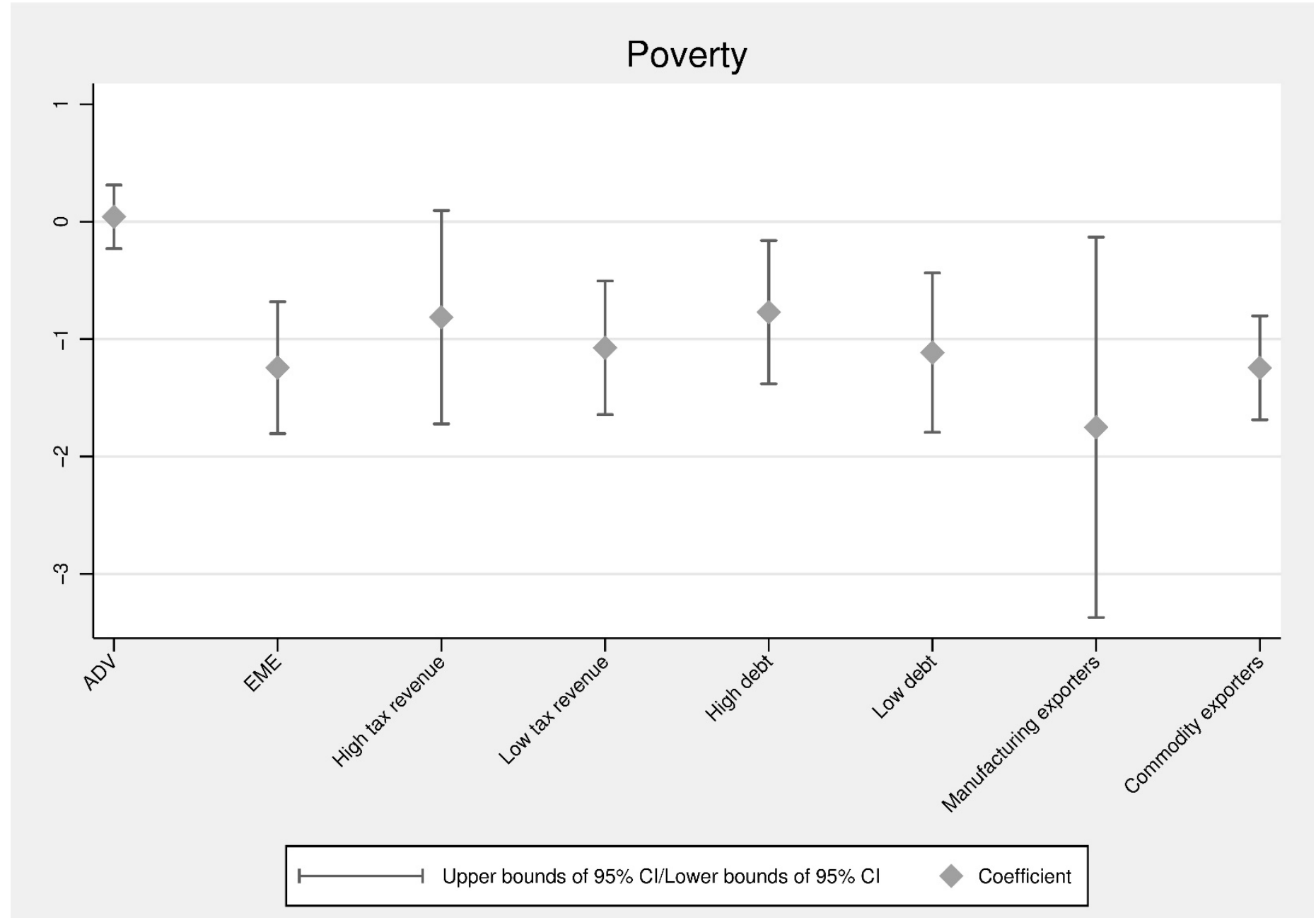

ADV - Advanced economies; EME - Emerging and developing economies.

Note: Fixed-effects regression results from equation (5) by group of countries. 
Figure 7: Impact of economic growth on other sustainable development goals by group of economies

High income, high tax revenue economies, and manufacturing exporters appear to focus more on reducing mortality ratio related to diseases and pollution exposure as well as increasing marine and terrestrial protected areas along with economic growth. Meanwhile, EME, low tax revenue economies, and commodity exporters show improvement in primary goals such as poverty reduction, increasing enrolment as well as access ratio to basic sanitation services and clean fuel and technology for cooking.

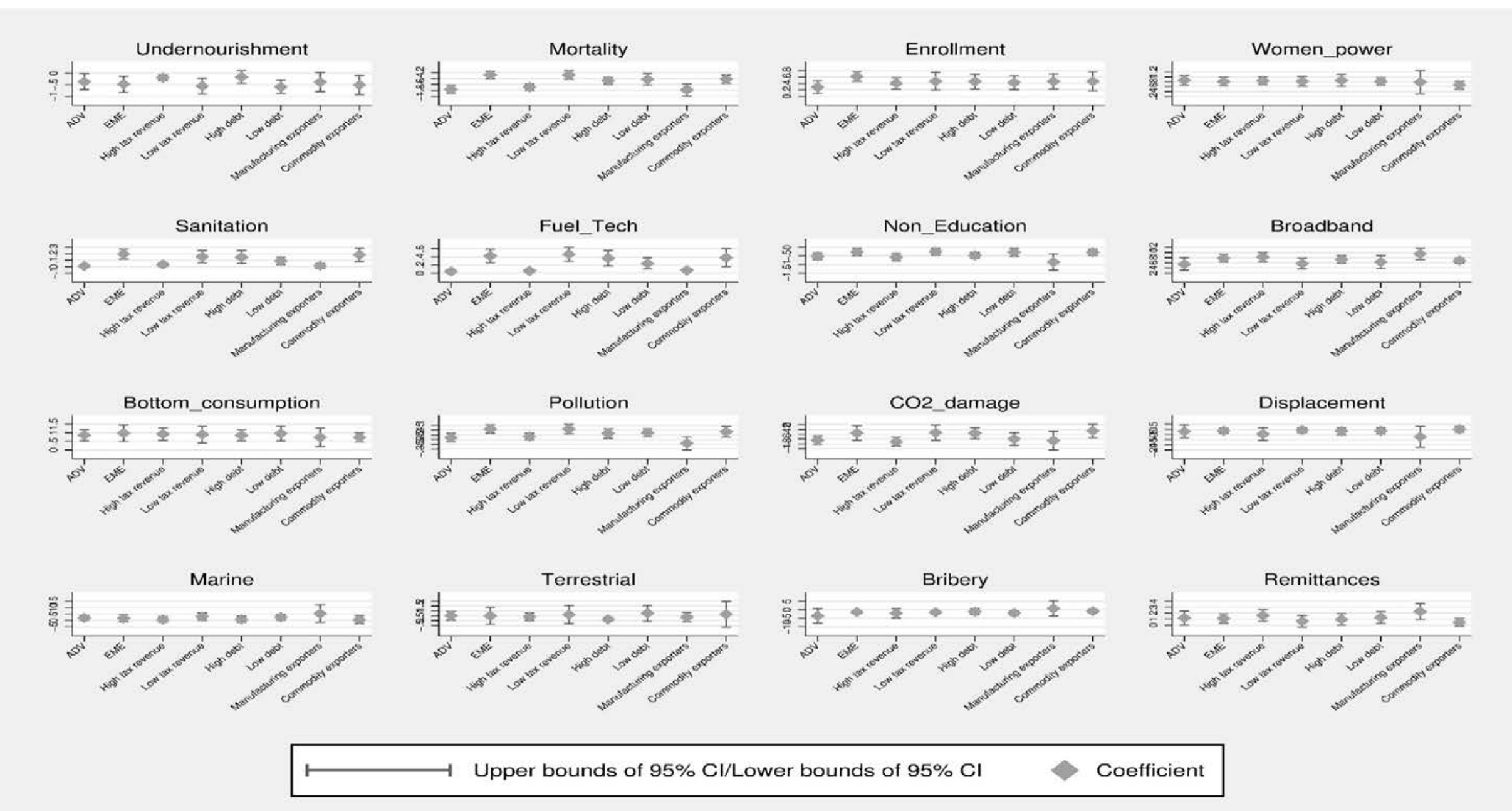

ADV - Advanced economies; EME - Emerging and developing economies.

Note: Fixed-effects regression results from equation (5) by group of countries. 


\section{Figure 8: Historical impacts of economic growth on selected sustainable development indicators}

The sampled countries seem to focus on achieving more access to primary necessities such as basic sanitation services and clean fuel and technology for cooking, reducing mortality rate associated with diseases, and protecting environment.

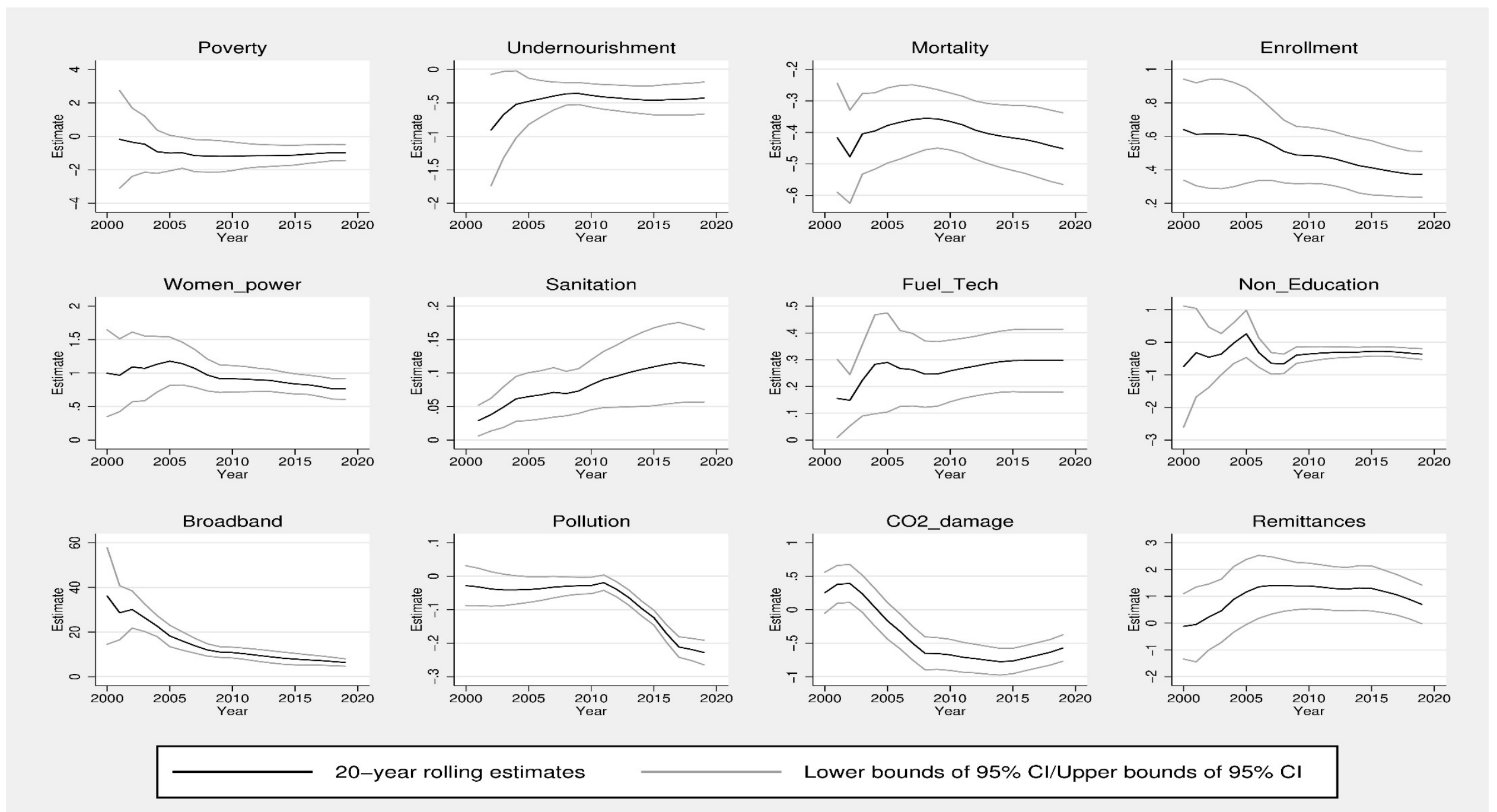

Note: 20-year rolling fixed-effects estimates for equation (5). Only 11 selected sustainable developments indicators are reported due to data insufficiency for the others. 


\section{APPENDIX DATA}

\section{Description of Variables}

Expense components

- Wage: General government expenditure on wage bill (\% of GDP), i.e., compensation of employees.

- Nonwage: General government expenditure on nonwage bills (\% of GDP), i.e., use of goods and services.

- Investment: General government expenditure on fixed capital (\% of GDP), i.e., consumption of fixed capital. ${ }^{4}$

- $\quad$ Subsidies: General government subsidies to firms (\% of GDP).

- $\quad$ Transfer: General government expenditure on social benefits (\% of GDP).

Tax revenue components

- PIT: Total income, capital gains, and profit taxes on individuals (\% of GDP), exclusive of resource revenues.

- $\quad$ CIT: Total nonresource income and profits taxes on corporations (\% of GDP).

- Other: Other direct taxes, including taxes on payroll and workforce and taxes on property (\% of GDP).

- INDT: Total nonresource indirect taxes, including taxes on goods and services, taxes on international trade, and other taxes (\% of GDP).

- $\quad$ SSC: Total social contributions (\% of GDP).

Unemployment rate: The unemployed share of the total labor force (modeled International Labour Organization estimate).

Gross government public debt-to-GDP ratio is sourced from International Monetary Fund's Historical public debt database.

Sustainable development goals

- $\quad$ Poverty: Poverty headcount ratio at national poverty lines (\% of the population).

\footnotetext{
${ }^{4}$ The 29 countries having fewer than 10 observations include Afghanistan; Albania; Argentina; Azerbaijan; Bahamas, The; Belarus; Bosnia and Herzegovina; Cabo Verde; Congo, Rep.; Costa Rica; Dominican Republic; Georgia; Honduras; Indonesia; Korea, Rep.; Macao SAR, China; Malaysia; Maldives; Mauritius; Mexico; Moldova; Mongolia; Morocco; Paraguay; Peru; Thailand;Trinidad and Tobago; Ukraine; Uruguay.
} 
- Undernourishment: Population below minimum level of dietary energy consumption (\% of the population).

- Mortality: Percent of 30-year-old-people who would die before their 70th birthday from cardiovascular disease, cancer, diabetes, or chronic respiratory disease.

- $\quad$ Enrollment: School enrollment at pre-primary education level (\% gross).

- Women power: Proportion of seats held by women in national parliaments (\%).

- Sanitation: People using at least basic sanitation services (\% of the population). These services include flush/pour flush to piped sewer systems, septic tanks or pit latrines, ventilated improved pit latrines, compositing toilets or pit latrines with slabs.

- $\quad$ Fuel-Tech: The population primarily use clean fuels and technologies for cooking (\% of the population).

- Non-education: Young people who are not in education, employment, or training to the population of the corresponding age group: youth (ages 15-24); persons ages 1529; or both age groups (\% of the youth population).

- $\quad$ Broadband: Fixed broadband subscriptions (per 100 people).

- Bottom consumption: Survey mean consumption or income per capita, Bottom $40 \%$ of the population (2011 purchasing power parity \$ per day).

- $\quad$ Pollution: $\mathrm{PM}_{2.5}$ air pollution mean annual exposure (micrograms per cubic meter).

- $\quad$ Carbon dioxide damage: Cost of damage because of carbon dioxide emissions from fossil fuel use and cement manufacture (\% of gross national income).

- Displacement: Internally displaced persons, new displacement associated with disasters (million cases).

- Marine: Marine protected areas (\% of territorial waters).

- $\quad$ Terrestrial: Terrestrial protected areas (\% of total land area).

- $\quad$ Bribery: Percentage of firms experiencing at least one bribe payment request across six public transactions dealing with utility access, permits, licenses, and taxes.

- Remittances: Personal remittances received, including personal transfers and compensation of employees (\% of GDP).

Export structure

- $\quad$ Commodity comprises agricultural materials, food, fuel, ores and metals. 
- Agricultural raw materials comprise SITC section 2 (crude materials except for fuels) excluding divisions 22, 27 (crude fertilizers and minerals excluding coal, petroleum, and precious stones), and 28 (metalliferous ores and scrap).

o Food comprises the commodities in SITC sections 0 (food and live animals), 1 (beverages and tobacco), and 4 (animal and vegetable oils and fats) and SITC division 22 (oil seeds, oil nuts, and oil kernels).

o Fuels comprise the commodities in SITC section 3 (mineral fuels, lubricants and related materials).

o Ores and metals comprise the commodities in SITC sections 27 (crude fertilizer, minerals nes); 28 (metalliferous ores, scrap); and 68 (non-ferrous metals).

- Manufactures comprise commodities in SITC sections 5 (chemicals), 6 (basic manufactures), 7 (machinery and transport equipment), and 8 (miscellaneous manufactured goods), excluding division 68 (non-ferrous metals).

- $\quad$ The commodity and manufactures trade balances are computed using their exports and imports data.

Political economy

- Political rights: a weighted score of electoral process, political pluralism, and participation, and functioning of government. Original political rights are measured on a one-to-seven scale, with one representing the highest degree of freedom and seven the lowest. In this study, we rescale political rights to $0.14-1$, with higher value representing more political freedom.

- Government effectiveness: a zero-to-one scaled measure of the bureaucracy quality, with higher points representing lower-risk countries, i.e., bureaucracy has the strength and expertise to govern without drastic changes in policy or interruptions in government services, and lower point the higher risk.

\section{Variables interpolation}

This section details how we filled up and interpolated missing data for the main components of general government expenses and tax revenue as well as SDGs indicators.

General government expenses are used for most of the sampled countries (). For 8 countries either having no observations or having too short data (fewer than 10 continuous observations), we use data for the central government instead. In particular, we use central government expense 
(excluding social security funds) data for Bahamas, The. For the rest of the 7 countries including Argentina, Cabo Verde, Dominican Republic, Malaysia, Maldives, Trinidad and Tobago, and Uruguay, we use central government expenses including social security funds data. These replacements will not have negative impacts on our outputs because their central government data are very close to their general government data when both are available at some points.

Furthermore, for Trinidad and Tobago, missing data in the year 2011 is generated as the average of the two adjacent data points for all 4 expense components. We also interpolated the missing data in 2015-2016 for Congo, Rep. of and in 2004-2005 for Mongolia, all for 4 main expense components.

For tax revenue, missing data on CIT and PIT (\% fo GDP) are replaced by their calculated CIT and PIT respectively using CIT and PIT average ratio to total income and profit taxes on corporations, including taxes on resource firms. Specifically for CIT and similarly for PIT of country $i$ at year $t$

$$
\operatorname{CIT}_{i, t}=\left(\left(\frac{1}{\left.t_{2}-t_{1}+1\right)} \sum_{t_{1}}^{t_{2}} \frac{\operatorname{CIT}_{i, t}}{\operatorname{TCIT}_{i, t}}\right) * \operatorname{TCIT}_{\text {Chile }, t}\right.
$$

, where $t_{1}, t_{2}$ are the starting and ending years for which tax data is available, and TCIT is total income and profit taxes on corporations, including taxes on resource firms. We replace missing data for several countries, each in different time periods, including Azerbaijan, Chile, Costa Rica, Dominican Republic, Indonesia, Uruguay. In addition, for India, we replace its missing tax data in 2012 with the average of their two adjacent values.

Similarly, for the SDG indicators, we also interpolated the missing data.

All the interpolated data is produced using command ipolate in Stata. This way, only the missing data in the middle of the series are filled in. 


\section{APPENDIX TABLE}

Table A1: Country list

\begin{tabular}{|c|c|c|c|c|c|c|}
\hline No. & Country & Period & $\begin{array}{c}\text { Development } \\
\text { level }\end{array}$ & Tax revenue & Public debt & $\begin{array}{l}\text { Economic } \\
\text { structure }\end{array}$ \\
\hline 1 & Afghanistan & 2007-2017 & EME & Low & High & \\
\hline 2 & Albania & 2006-2019 & EME & Low & High & \\
\hline 3 & Argentina & $1992-2004$ & EME & Low & Low & $\mathrm{C}$ \\
\hline 4 & Australia & $2000-2018$ & ADV & High & Low & C \\
\hline 5 & Austria & 1996-2019 & ADV & High & High & $M$ \\
\hline 6 & Azerbaijan & $2009-2019$ & EME & Low & Low & $\mathrm{C}$ \\
\hline 7 & Bahamas, The & $1992-2005$ & EME & Low & Low & \\
\hline 8 & Belarus & 2004-2019 & EME & High & Low & \\
\hline 9 & Belgium & 1996-2019 & ADV & High & High & $M$ \\
\hline 10 & Bosnia and Herzegovina & $2007-2019$ & EME & High & Low & \\
\hline 11 & Brazil & 2011-2019 & EME & High & High & C \\
\hline 12 & Bulgaria & 1996-2019 & EME & Low & High & C \\
\hline 13 & Cabo Verde & $2006-2017$ & EME & Low & High & \\
\hline 14 & Canada & $1998-2019$ & ADV & High & High & C \\
\hline 15 & Chile & 2001-2019 & EME & Low & High & $\mathrm{C}$ \\
\hline 16 & Congo, Rep. & 2004-2018 & EME & Low & High & C \\
\hline 17 & Costa Rica & 2003-2019 & EME & Low & High & C \\
\hline 18 & Croatia & 2003-2019 & EME & High & High & \\
\hline 19 & Cyprus & $1996-2019$ & ADV & High & Low & \\
\hline 20 & Czech Republic & 1996-2019 & ADV & High & Low & $M$ \\
\hline 21 & Denmark & 1996-2019 & ADV & High & Low & $\mathrm{C}$ \\
\hline 22 & Dominican Republic & 1994-2019 & EME & Low & Low & \\
\hline 23 & El Salvador & 2003-2019 & EME & Low & Low & \\
\hline 24 & Estonia & $1996-2019$ & ADV & High & Low & \\
\hline 25 & Finland & 1996-2019 & ADV & High & Low & $M$ \\
\hline 26 & France & 1996-2019 & ADV & High & High & \\
\hline
\end{tabular}




\begin{tabular}{|c|c|c|c|c|c|c|}
\hline 27 & Georgia & 2005-2019 & EME & Low & High & \\
\hline 28 & Germany & $1992-2019$ & ADV & High & High & $M$ \\
\hline 29 & Greece & $1996-2019$ & ADV & High & High & \\
\hline 30 & Honduras & 2004-2014 & EME & Low & High & C \\
\hline 31 & Hong Kong SAR, China & 2003-2018 & ADV & Low & Low & \\
\hline 32 & Hungary & $1996-2019$ & EME & High & High & $\mathrm{M}$ \\
\hline 33 & Iceland & 1999-2019 & ADV & High & Low & $\mathrm{C}$ \\
\hline 34 & Indonesia & $2009-2019$ & EME & Low & Low & C \\
\hline 35 & Ireland & 1996-2019 & ADV & High & High & C \\
\hline 36 & Israel & 2001-2019 & ADV & High & High & \\
\hline 37 & Italy & $1996-2019$ & ADV & High & High & $\mathrm{M}$ \\
\hline 38 & Japan & $1995-2018$ & ADV & Low & High & $\mathrm{M}$ \\
\hline 39 & Korea, Rep. & 2008-2019 & ADV & Low & Low & $M$ \\
\hline 40 & Latvia & 1996-2019 & ADV & High & Low & \\
\hline 41 & Lithuania & 1996-2019 & ADV & High & Low & \\
\hline 42 & Luxembourg & $1996-2019$ & ADV & High & Low & \\
\hline 43 & Macao SAR, China & $1997-2019$ & ADV & Low & Low & \\
\hline 44 & Malaysia & $1992-2001$ & EME & Low & High & C \\
\hline 45 & Maldives & 1996-2009 & EME & Low & High & \\
\hline 46 & Malta & 1996-2019 & ADV & High & Low & \\
\hline 47 & Mauritius & 2003-2019 & EME & Low & High & \\
\hline 48 & Mexico & 2009-2018 & EME & Low & Low & C \\
\hline 49 & Moldova & 2004-2019 & EME & Low & High & \\
\hline 50 & Mongolia & 1993-2007 & EME & Low & High & C \\
\hline 51 & Morocco & 2003-2011 & EME & Low & High & \\
\hline 52 & Netherlands & 1996-2019 & ADV & High & High & C \\
\hline 53 & New Zealand & 2010-2019 & ADV & High & High & $\mathrm{C}$ \\
\hline 54 & Norway & $1996-2019$ & ADV & High & Low & $C$ \\
\hline 55 & Paraguay & 2006-2019 & EME & Low & Low & $C$ \\
\hline 56 & Peru & 1996-2019 & EME & Low & Low & C \\
\hline 57 & Poland & 1996-2019 & EME & High & High & \\
\hline 58 & Portugal & 1996-2019 & ADV & High & High & \\
\hline
\end{tabular}




\begin{tabular}{|l|l|c|c|c|c|c|}
\hline 59 & Romania & $1996-2019$ & EME & Low & Low & \\
\hline 60 & Slovak Republic & $1996-2019$ & ADV & High & Low & M \\
\hline 61 & Slovenia & $1996-2019$ & ADV & High & Low & M \\
\hline 62 & South Africa & $1997-2019$ & EME & Low & Low & C \\
\hline 63 & Spain & $1996-2019$ & ADV & High & Low & \\
\hline 64 & Sweden & $1996-2019$ & ADV & High & High & M \\
\hline 65 & Switzerland & $1992-2019$ & ADV & Low & Low & M \\
\hline 66 & Thailand & $2001-2019$ & EME & Low & Low & M \\
\hline 67 & Trinidad and Tobago & $2002-2018$ & EME & Low & Low & C \\
\hline 68 & Turkey & $2009-2019$ & EME & Low & Low & \\
\hline 69 & Ukraine & $2003-2019$ & EME & High & Low & M \\
\hline 70 & United Kingdom & $1996-2019$ & ADV & High & High & \\
\hline 71 & United States & $2002-2019$ & ADV & Low & High & \\
\hline 72 & Uruguay & $1992-2016$ & EME & Low & High & C \\
\hline
\end{tabular}

$\mathrm{EME}=$ Emerging and developing economies; $\mathrm{ADV}=$ Advanced economies; $\mathrm{M}=$ Manufacturing exporters; $\mathrm{C}=$ Commodity exporters.

Note: Total tax revenue and public debt are in percentage of GDP. An economy is classified as a high (low) tax revenue group if their average total tax revenue during the 1991-2019 period is higher (lower) than the sampled median total tax revenue, which is $28.8 \%$ of GDP. Similarly, an economy is classified as a high (low) public debt group if their average public debt during the 1991-2019 period is higher (lower) than the sampled median public debt, which is $42.7 \%$ of GDP. An economy is classified as a commodity (manufacturing) exporter if their median of annual commodity (manufacturing) trade balance, in percentage of GDP, over the 1990-2020 period is positive. 
Table A2: Mean comparison tests on SDGs and growth by group of economies

Overall, high income, high tax revenue, low debt economies, and manufacturing exporters are featured with better sustainable development outcomes.

\begin{tabular}{|c|c|c|c|c|c|c|c|c|}
\hline \multirow[t]{2}{*}{ Variables } & \multicolumn{2}{|c|}{ Development level } & \multicolumn{2}{|c|}{ Tax revenue } & \multicolumn{2}{|c|}{ Public debt } & \multicolumn{2}{|c|}{ Economic structure } \\
\hline & EME & ADV & Low & High & Low & High & $\begin{array}{l}\text { Commodity } \\
\text { exporters }\end{array}$ & $\begin{array}{c}\text { Manufacturing } \\
\text { exporters }\end{array}$ \\
\hline \multirow[t]{2}{*}{ Poverty } & 24.5 & $15.3^{* * *}$ & 26.3 & $15.7 * * *$ & 19.7 & 20.4 & 23.6 & $15.7^{* * *}$ \\
\hline & (15) & (3.7) & $(14.2)$ & $(7.4)$ & $(13.2)$ & $(10)$ & $(15.2)$ & $(10.5)$ \\
\hline \multirow[t]{2}{*}{ Undernourishment } & 7.7 & $2.9 * * *$ & 8.2 & $2.7^{* * *}$ & 4.7 & $5.5^{* *}$ & 6.6 & $3.2^{* * *}$ \\
\hline & (7.8) & $(2)$ & (7.9) & $(0.7)$ & (4.1) & $(7.4)$ & (7.9) & $(2.2)$ \\
\hline \multirow[t]{2}{*}{ Mortality } & 21.6 & $13.5^{* * *}$ & 19.7 & $15.5^{* * *}$ & 17.4 & 17.2 & 17.4 & $15.1 * * *$ \\
\hline & (7.3) & $(4.3)$ & (7.9) & (5.9) & (6.9) & $(7.4)$ & (7.8) & (6.1) \\
\hline \multirow[t]{2}{*}{ Enrollment } & 61.8 & $90 * * *$ & 64.7 & $87.8^{* * *}$ & 76.3 & $79.5^{* *}$ & 71 & $89.6 * * *$ \\
\hline & $(24.7)$ & $(16.8)$ & $(26.2)$ & (18.4) & $(26.1)$ & (23.3) & $(28.8)$ & (16) \\
\hline \multirow[t]{2}{*}{ Women power } & 18.1 & $24.6 * * *$ & 18.2 & $24.1 * * *$ & 22.6 & $20.7 * * *$ & 24.4 & $22.9 *$ \\
\hline & (9.1) & $(10.6)$ & (9.1) & $(10.6)$ & $(10.3)$ & $(10.5)$ & (11.1) & $(12.3)$ \\
\hline \multirow[t]{2}{*}{ Sanitation } & 83 & $98.4 * * *$ & 83.6 & $97.6 * * *$ & 92.8 & $89.9 * * *$ & 85.9 & $98.8 * * *$ \\
\hline & (17.9) & $(2.8)$ & $(18.6)$ & (3.4) & $(9.5)$ & (18.1) & $(19.2)$ & (1.5) \\
\hline \multirow[t]{2}{*}{ Fuel-Tech } & 76.3 & $98.6 * * *$ & 76.2 & $97.2^{* * *}$ & 89.2 & $87.2^{*}$ & 82.8 & $96.5^{* * *}$ \\
\hline & $(22.7)$ & (3.2) & $(23.3)$ & $(7.2)$ & $(15.2)$ & $(22.4)$ & $(24.5)$ & $(7.3)$ \\
\hline \multirow[t]{2}{*}{ Non-education } & 21.5 & $10.4 * * *$ & 20.3 & $11.4^{* * *}$ & 14.2 & $15.6 * * *$ & 16.5 & $10.1 * * *$ \\
\hline & (6.6) & $(4.1)$ & (7.9) & $(4.9)$ & (8.2) & (7) & $(8)$ & $(4.1)$ \\
\hline \multirow[t]{2}{*}{ Broadband } & 8.2 & $23 * * *$ & 10.7 & $21.1 * * *$ & 16.8 & 16.5 & 15.1 & $20.4^{* * *}$ \\
\hline & (8.4) & $(12.8)$ & $(11.5)$ & $(12.8)$ & $(13.5)$ & $(13.1)$ & (13.9) & (13.1) \\
\hline \multirow[t]{2}{*}{ Bottom consumption } & 7.3 & $23.5^{* * *}$ & 9.5 & $20.8^{* * *}$ & 17.1 & 16.7 & 17.5 & $21.6^{* *}$ \\
\hline & (3.1) & (7.8) & (8.6) & (8.7) & (10.9) & (9.4) & $(12.6)$ & $(8.4)$ \\
\hline \multirow[t]{2}{*}{ Pollution } & 24.1 & $13.7^{* * *}$ & 23.1 & $14.9 * * *$ & 18.2 & 18.5 & 18.5 & $16.9 * *$ \\
\hline & (9.7) & (4.9) & (10.6) & (5.7) & $(7.8)$ & (10.1) & (9.7) & $(6.2)$ \\
\hline \multirow{2}{*}{$\begin{array}{l}\text { Carbon dioxide } \\
\text { damage }\end{array}$} & 2.4 & $0.9 * * *$ & 1.9 & $1.3 * * *$ & 1.7 & $1.3^{* * *}$ & 1.9 & $1.4^{* * *}$ \\
\hline & (2.3) & $(0.6)$ & $(2.1)$ & (1.5) & (1.8) & (1.7) & (2.4) & (1.9) \\
\hline \multirow[t]{2}{*}{ Displacement } & 76.5 & 67.2 & 118.2 & $16.7^{* * *}$ & 63.2 & 80.9 & 94.5 & 70.6 \\
\hline & (235.9) & (253.3) & (318.6) & (49.2) & $(200.2)$ & (277.3) & (253.4) & (233.3) \\
\hline
\end{tabular}




\begin{tabular}{|c|c|c|c|c|c|c|c|c|}
\hline Marine & $\begin{array}{c}6.8 \\
(8.8)\end{array}$ & $\begin{array}{c}20.5^{* * *} \\
(28.8)\end{array}$ & $\begin{array}{c}7.1 \\
(10.6)\end{array}$ & $\begin{array}{c}19.5^{* * *} \\
(27.8)\end{array}$ & $\begin{array}{l}13.8 \\
(29.1)\end{array}$ & $\begin{array}{c}14.8 \\
(14.8)\end{array}$ & $\begin{array}{c}10.5 \\
(12.6)\end{array}$ & $\begin{array}{c}26.5^{* *} \\
(43.9)\end{array}$ \\
\hline Terrestrial & $\begin{array}{c}17.1 \\
(12.2)\end{array}$ & $\begin{array}{c}23.4^{* * *} \\
(10.2)\end{array}$ & $\begin{array}{c}16.8 \\
(11.4)\end{array}$ & $\begin{array}{c}23.3^{* * *} \\
(10.9)\end{array}$ & $\begin{array}{c}19.2 \\
(11.6)\end{array}$ & $\begin{array}{c}22^{*} \\
(11.4)\end{array}$ & $\begin{array}{l}19.7 \\
(9.4)\end{array}$ & $\begin{array}{c}23.1 \\
(12.4)\end{array}$ \\
\hline Bribery & $\begin{array}{l}13.9 \\
(12)\end{array}$ & $\begin{array}{c}3.4^{* * *} \\
(2.6)\end{array}$ & $\begin{array}{c}14.1 \\
(11.2)\end{array}$ & $\begin{array}{l}8.2^{* * *} \\
(11.3)\end{array}$ & $\begin{array}{c}11.7 \\
(11.8)\end{array}$ & $\begin{array}{c}11.5 \\
(11.3)\end{array}$ & $\begin{array}{c}13.7 \\
(10.4)\end{array}$ & $\begin{array}{c}11.5 \\
(16.3)\end{array}$ \\
\hline Remittances & $\begin{array}{l}4.2 \\
(6)\end{array}$ & $\begin{array}{c}0.8^{* * *} \\
(1)\end{array}$ & $\begin{array}{l}3.5 \\
(6)\end{array}$ & $\begin{array}{c}1.3^{* * *} \\
(2.1)\end{array}$ & $\begin{array}{c}2.1 \\
(3.6)\end{array}$ & $\begin{array}{c}2.4 \\
(4.9)\end{array}$ & $\begin{array}{c}1.2 \\
(2.9)\end{array}$ & $\begin{array}{c}1 \\
(1.4)\end{array}$ \\
\hline Constant GDP & $\begin{array}{c}1.57 \mathrm{e}+11 \\
(3.18 \mathrm{e}+11)\end{array}$ & $\begin{array}{c}9.72 \mathrm{e}+11^{* * *} \\
(2.15 \mathrm{e}+12)\end{array}$ & $\begin{array}{c}5.75 e+11 \\
(2.04 e+12)\end{array}$ & $\begin{array}{c}5.36 e+11 \\
(7.47 e+11)\end{array}$ & $\begin{array}{c}2.15 e+11 \\
(3.06 e+11)\end{array}$ & $\begin{array}{c}8.91 \mathrm{e}+11 * * * \\
(2.14 \mathrm{e}+12)\end{array}$ & $\begin{array}{c}2.68 e+11 \\
(4.11 e+11)\end{array}$ & $\begin{array}{c}8.57 \mathrm{e}+11^{* * *} \\
(1.31 \mathrm{e}+12)\end{array}$ \\
\hline
\end{tabular}

Note: Mean and standard deviation statistics by group of economies. Standard deviations are in brackets. ${ }^{*}, * * * *$ significant at $10 \%, 5 \%$, and $1 \%$ respectively for ttest for mean difference by group of economies. Details of ttest are provided upon request. 
Table A3. Sustainable development, economic growth, total tax revenue, and government effectiveness

Higher total tax revenue and higher government effectiveness are positively associated with higher GDP, which in turn is positively associated with better sustainable development outcomes. Next, how about primary expenses?

\begin{tabular}{|c|c|c|c|c|c|c|c|c|c|}
\hline & (1) & $(2)$ & (3) & (4) & (5) & (6) & (7) & (8) & (9) \\
\hline & Povertyt & Undernourishment $_{\mathrm{t}}$ & Mortalityt & Enrollment $_{t}$ & $\begin{array}{l}\text { Women } \\
\text { powert }\end{array}$ & Sanitation $_{\mathrm{t}}$ & Fuel-Techt & Non-education $_{t}$ & Broadband $_{\mathrm{t}}$ \\
\hline \multicolumn{10}{|c|}{ First-stage: Dependent variable $=\mathrm{GDP}_{\mathrm{t}-1}$} \\
\hline Tax revenue $\mathrm{t}_{\mathrm{t} 2}$ & $\begin{array}{c}0.266 * * * \\
(15.13)\end{array}$ & $\begin{array}{c}0.329 * * * \\
(27.13)\end{array}$ & $\begin{array}{c}0.330 * * * \\
(28.32)\end{array}$ & $\begin{array}{c}0.279 * * * \\
(15.62)\end{array}$ & $\begin{array}{c}0.294^{* * *} \\
(15.32)\end{array}$ & $\begin{array}{c}0.335 * * * \\
(29.34)\end{array}$ & $\begin{array}{c}0.327^{* * *} \\
(27.80)\end{array}$ & $\begin{array}{c}0.367 * * * \\
(38.58)\end{array}$ & $\begin{array}{c}0.340 * * * \\
(26.82)\end{array}$ \\
\hline \multirow[t]{2}{*}{$\begin{array}{l}\text { Government } \\
\text { effectivenesst-2 }\end{array}$} & -0.279 & 0.0559 & 0.124 & -0.0815 & 0.0404 & 0.130 & $0.209 *$ & 0.152 & 0.135 \\
\hline & $(-1.59)$ & $(0.53)$ & $(1.25)$ & $(-0.90)$ & $(0.47)$ & $(1.31)$ & $(2.54)$ & $(1.14)$ & $(1.39)$ \\
\hline F-statistic & 130.530 & 452.044 & 486.863 & 144.244 & 136.211 & 530.503 & 412.333 & 925.227 & 455.981 \\
\hline p-value & 0.000 & 0.000 & 0.000 & 0.000 & 0.000 & 0.000 & 0.000 & 0.000 & 0.000 \\
\hline \multicolumn{10}{|c|}{ Second-stage: Dependent variable $=$ SDGs } \\
\hline $\mathrm{GDP}_{\mathrm{t}-1}$ & $\begin{array}{c}-1.437^{* * *} \\
(0.308)\end{array}$ & $\begin{array}{c}-0.447 * * * \\
(0.048)\end{array}$ & $\begin{array}{c}-0.549 * * * \\
(0.032)\end{array}$ & $\begin{array}{c}0.573 * * * \\
(0.034)\end{array}$ & $\begin{array}{c}0.897 * * * \\
(0.052)\end{array}$ & $\begin{array}{c}0.124 * * * \\
(0.009)\end{array}$ & $\begin{array}{c}0.254 * * * \\
(0.020)\end{array}$ & $\begin{array}{c}-0.222 * * * \\
(0.045)\end{array}$ & $\begin{array}{c}8.152 * * * \\
(0.337)\end{array}$ \\
\hline \multicolumn{10}{|c|}{ Overidentification test } \\
\hline Chi-squared & 6.200 & 1.757 & 16.380 & 26.148 & 0.106 & 6.762 & 0.000 & 0.812 & 5.287 \\
\hline$p$-value & 0.013 & 0.185 & 0.000 & 0.000 & 0.745 & 0.009 & 0.999 & 0.368 & 0.021 \\
\hline \multicolumn{10}{|l|}{ Endogeneity test } \\
\hline Chi-squared & 2.744 & 0.874 & 16.836 & 8.799 & 19.375 & 44.265 & 22.789 & 25.416 & 37.319 \\
\hline$p$-value & 0.098 & 0.350 & 0.000 & 0.003 & 0.000 & 0.000 & 0.000 & 0.000 & 0.000 \\
\hline Observations & 566 & 1015 & 1061 & 1100 & 1164 & 1075 & 888 & 817 & 1041 \\
\hline$p$-value & 0.000 & 0.000 & 0.000 & 0.000 & 0.000 & 0.000 & 0.000 & 0.000 & 0.000 \\
\hline
\end{tabular}


Bottom consumption $_{t} \quad$ Pollution $_{t}$ damage $_{t}$

Displacement $_{t}$ Marine $_{t}$ Terrestrial $_{t}$ Bribery $_{t} \quad$ Remittances $_{t}$ First-stage: Dependent variable $=\mathrm{GDP}_{\mathrm{t}-1}$

\begin{tabular}{|c|c|c|c|c|c|c|c|c|}
\hline \multicolumn{9}{|c|}{ First-stage: Dependent variable $=\mathrm{GDP}_{\mathrm{t}-1}$} \\
\hline Tax revenue $\mathrm{t}_{\mathrm{t}-2}$ & $0.401 * * *$ & $0.266^{* * *}$ & $0.280 * * *$ & $0.338 * * *$ & $0.335 * * *$ & $\begin{array}{c}0.331 * * * \\
(634)\end{array}$ & $\begin{array}{c}0.243 * * * \\
\text { (9 39) }\end{array}$ & $0.287^{* * *}$ \\
\hline \multirow{2}{*}{ Government effectiveness $\mathrm{t}_{-2}$} & $\begin{array}{l}(10.03) \\
-0.403\end{array}$ & $\begin{array}{l}(15.03) \\
-0.0718\end{array}$ & $\begin{array}{l}(10.53) \\
-0.0832\end{array}$ & $0.521 * * *$ & $0.542 * * *$ & 0.142 & -0.553 & -0.0803 \\
\hline & $(-1.07)$ & $(-0.83)$ & $(-0.93)$ & (6.15) & $(5.00)$ & $(0.53)$ & $(-0.73)$ & $(-0.89)$ \\
\hline F-statistics & 50.336 & 130.923 & 158.095 & 61.701 & 19.616 & 20.093 & 44.146 & 155.318 \\
\hline p-value & 0.000 & 0.000 & 0.000 & 0.000 & 0.000 & 0.000 & 0.000 & 0.000 \\
\hline \multicolumn{9}{|c|}{ Second-stage: Dependent variable $=\mathrm{SDG}_{\mathrm{t}}$} \\
\hline \multirow[t]{2}{*}{$\mathrm{GDP}_{\mathrm{t}-1}$} & $1.115^{* * *}$ & $-0.253^{* * *}$ & $-0.620 * * *$ & $-3.559 * *$ & $4.729 * * *$ & 0.318 & $-1.982 * * *$ & $1.722 * * *$ \\
\hline & $(0.115)$ & $(0.015)$ & (0.069) & $(1.587)$ & $(1.608)$ & $(0.289)$ & $(0.306)$ & $(0.183)$ \\
\hline \multicolumn{9}{|l|}{ Overidentification test } \\
\hline Chi-squared & 0.038 & 3.247 & 23.368 & 0.736 & 0.688 & 0.000 & 0.478 & 0.813 \\
\hline$p$-value & 0.846 & 0.072 & 0.000 & 0.391 & 0.407 & 0.984 & 0.489 & 0.367 \\
\hline \multicolumn{9}{|l|}{ Endogeneity test } \\
\hline Chi-squared & 6.973 & 7.810 & 2.966 & 3.314 & 4.323 & 1.208 & 11.313 & 16.815 \\
\hline$p$-value & 0.008 & 0.005 & 0.085 & 0.069 & 0.038 & 0.272 & 0.001 & 0.000 \\
\hline Observations & 288 & 1085 & 1200 & 432 & 144 & 174 & 275 & 1186 \\
\hline$p$-value & 0.000 & 0.000 & 0.000 & 0.026 & 0.004 & 0.275 & 0.000 & 0.000 \\
\hline
\end{tabular}

GDP = gross domestic product; SDGs = sustainable development goals.

Note: 1 . Two-stage least squares regression results for equation (5) whereas in the first stage, gross domestic product is regressed on total tax revenue and government effectiveness. Total tax revenue is computed from Total tax revenue (\% of GDP) and nominal GDP. All sustainable development goals, gross domestic product, and total tax revenue are in natural logarithm. Robust standard errors in parentheses. $*, * *, * * *$ significant at $10 \%, 5 \%$, and $1 \%$ respectively. 2. First-stage test is under the null hypothesis that the coefficients of the excluded instruments are jointly equal to zero. Overidentification test is under the joint null hypothesis that the instruments are valid, i.e., uncorrelated with the error term, and that the excluded instruments are correctly excluded from the estimated equation. Endogeneity test is under the null hypothesis that the specified endogenous regressors can be treated as exogenous. 
Table A4. Sustainable development, economic growth, primary expenses, and government effectiveness

Higher primary expenses and higher government effectiveness are also positively associated with higher GDP, which in turn is positively associated with better sustainable development outcomes.

\begin{tabular}{|c|c|c|c|c|c|c|c|c|c|}
\hline & $(1)$ & $(2)$ & (3) & (4) & (5) & (6) & (7) & (8) & (9) \\
\hline & Povertyt & Undernourishment $t_{t}$ & Mortalityt & Enrollment $_{\mathrm{t}}$ & $\begin{array}{l}\text { Women } \\
\text { powert }\end{array}$ & Sanitation $_{\mathrm{t}}$ & Fuel-Techt & Non-education $_{t}$ & Broadband $_{\mathrm{t}}$ \\
\hline \multicolumn{10}{|c|}{ First-stage: Dependent variable $=\mathrm{GDP}_{\mathrm{t}-1}$} \\
\hline \multirow[t]{2}{*}{$\begin{array}{l}\text { Primary } \\
\text { expensest-2 }\end{array}$} & $0.252^{* * *}$ & $0.312^{* * *}$ & $0.315^{* * *}$ & $0.265 * * *$ & $0.283^{* * *}$ & $0.320 * * *$ & $0.307^{* * *}$ & $0.350 * * *$ & $0.320 * * *$ \\
\hline & $(15.19)$ & $(27.11)$ & $(28.42)$ & $(16.17)$ & $(15.52)$ & $(29.23)$ & $(28.20)$ & (37.99) & $(27.13)$ \\
\hline \multirow[t]{2}{*}{$\begin{array}{l}\text { Government } \\
\text { effectivenesst-2 }\end{array}$} & -0.236 & 0.105 & 0.173 & -0.0347 & 0.0683 & 0.179 & $0.276^{* *}$ & 0.185 & 0.167 \\
\hline & $(-1.25)$ & $(0.92)$ & $(1.62)$ & $(-0.38)$ & $(0.76)$ & $(1.67)$ & $(3.01)$ & $(1.65)$ & $(1.64)$ \\
\hline F-statistic & 130.225 & 449.291 & 490.205 & 153.843 & 138.053 & 527.101 & 421.884 & 845.080 & 464.983 \\
\hline p-value & 0.000 & 0.000 & 0.000 & 0.000 & 0.000 & 0.000 & 0.000 & 0.000 & 0.000 \\
\hline \multicolumn{10}{|c|}{ Second-stage: Dependent variable $=$ SDGs } \\
\hline $\mathrm{GDP}_{\mathrm{t}-1}$ & $\begin{array}{c}-1.439 * * * \\
(0.311)\end{array}$ & $\begin{array}{c}-0.452 * * * \\
(0.049)\end{array}$ & $\begin{array}{c}-0.590 * * * \\
(0.035)\end{array}$ & $\begin{array}{c}0.586 * * * \\
(0.035)\end{array}$ & $\begin{array}{c}0.941 * * * \\
(0.052)\end{array}$ & $\begin{array}{c}0.115 * * * \\
(0.008)\end{array}$ & $\begin{array}{c}0.238 * * * \\
(0.019)\end{array}$ & $\begin{array}{c}-0.140 * * * \\
(0.045)\end{array}$ & $\begin{array}{c}8.528 * * * \\
(0.341)\end{array}$ \\
\hline \multicolumn{10}{|c|}{ Overidentification test } \\
\hline Chi-squared & 6.196 & 1.765 & 14.995 & 26.464 & 0.061 & 6.712 & 0.017 & 0.631 & 5.304 \\
\hline p-value & 0.013 & 0.184 & 0.000 & 0.000 & 0.805 & 0.010 & 0.898 & 0.427 & 0.021 \\
\hline \multicolumn{10}{|l|}{ Endogeneity test } \\
\hline Chi-squared & 2.630 & 0.859 & 39.301 & 11.388 & 29.971 & 34.168 & 6.528 & 55.079 & 59.443 \\
\hline p-value & 0.105 & 0.354 & 0.000 & 0.001 & 0.000 & 0.000 & 0.011 & 0.000 & 0.000 \\
\hline Observations & 566 & 1015 & 1061 & 1100 & 1164 & 1075 & 888 & 817 & 1041 \\
\hline$p$-value & 0.000 & 0.000 & 0.000 & 0.000 & 0.000 & 0.000 & 0.000 & 0.002 & 0.000 \\
\hline
\end{tabular}


Bottom consumption $\mathrm{t}_{\mathrm{t}}$

Pollution $_{\mathrm{t}}$ Carbon dioxide

Displacement $_{t} \quad$ Marine $_{t} \quad$ Terrestrial $_{t}$

Briberyt

Remittances $s_{t}$

\begin{tabular}{|c|c|c|c|c|c|c|c|c|}
\hline \\
\hline \multicolumn{9}{|c|}{ First-stage: Dependent variable $=\mathrm{GDP}_{\mathrm{t}-1}$} \\
\hline \multirow[t]{2}{*}{ Primary expensest-2 } & $0.322 * * *$ & $0.253 * * *$ & $0.268 * * *$ & $0.299 * * *$ & $0.496 * * *$ & $0.478 * * *$ & $0.221 * * *$ & $0.274^{* * *}$ \\
\hline & $(8.46)$ & $(15.56)$ & $(16.89)$ & $(12.14)$ & $(8.00)$ & (9.32) & $(9.47)$ & $(16.58)$ \\
\hline \multirow[t]{2}{*}{ Government effectivenesss $\mathrm{t}_{-2}$} & -0.222 & -0.0233 & -0.0371 & 0.0126 & $0.311^{*}$ & -0.0917 & -0.420 & -0.0334 \\
\hline & $(-0.59)$ & $(-0.26)$ & $(-0.40)$ & $(0.06)$ & $(2.31)$ & $(-0.33)$ & $(-0.55)$ & $(-0.36)$ \\
\hline F-statistics & 35.798 & 139.798 & 164.844 & 73.755 & 32.821 & 44.750 & 44.911 & 160.724 \\
\hline p-value & 0.000 & 0.000 & 0.000 & 0.000 & 0.000 & 0.000 & 0.000 & 0.000 \\
\hline \multicolumn{9}{|c|}{ Second-stage: Dependent variable $=\mathrm{SDGs}_{\mathrm{t}}$} \\
\hline \multirow[t]{2}{*}{$\mathrm{GDP}_{\mathrm{t}-1}$} & $0.992 * * *$ & $-0.266 * * *$ & $-0.636 * * *$ & $-2.766^{*}$ & $4.321 * *$ & 0.522 & $-2.107 * * *$ & $1.713 * * *$ \\
\hline & $(0.118)$ & $(0.016)$ & $(0.069)$ & $(1.487)$ & $(1.873)$ & $(0.495)$ & $(0.310)$ & $(0.183)$ \\
\hline \multicolumn{9}{|l|}{ Overidentification test } \\
\hline Chi-squared & 0.013 & 2.841 & 22.975 & 0.791 & 0.676 & 0.027 & 0.507 & 0.804 \\
\hline$p$-value & 0.909 & 0.092 & 0.000 & 0.374 & 0.411 & 0.870 & 0.477 & 0.370 \\
\hline \multicolumn{9}{|l|}{ Endogeneity test } \\
\hline Chi-squared & 0.578 & 15.589 & 4.199 & 0.763 & 1.687 & 0.000 & 9.734 & 15.383 \\
\hline$p$-value & 0.447 & 0.000 & 0.040 & 0.382 & 0.194 & 0.994 & 0.002 & 0.000 \\
\hline Observations & 288 & 1085 & 1200 & 432 & 144 & 174 & 275 & 1186 \\
\hline $\mathrm{p}$-value & 0.000 & 0.000 & 0.000 & 0.064 & 0.024 & 0.296 & 0.000 & 0.000 \\
\hline
\end{tabular}

GDP = gross domestic product; SDGs = sustainable development goals.

Note: 1. Two-stage least squares regression results for equation (5) whereas in the first stage, gross domestic product is regressed on primary expenses and government effectiveness. Primary expenses is computed from Primary expenses (\% of GDP) and nominal GDP. All sustainable development goals, gross domestic product, and primary expenses are in natural logarithm. Robust standard errors in parentheses. ${ }^{*}, * *, * * *$ significant at $10 \%, 5 \%$, and $1 \%$ respectively.

2. First-stage test is under the null hypothesis that the coefficients of the excluded instruments are jointly equal to zero. Overidentification test is under the joint null hypothesis that the instruments are valid, i.e., uncorrelated with the error term, and that the excluded instruments are correctly excluded from the estimated equation. Endogeneity test is under the null hypothesis that the specified endogenous regressors can be treated as exogenous. 


\section{APPENDIX FIGURES}

Figure A1. Histograms of sustainable development goals and economic growth

Sustainable development indicators and GDP do not follow normal distribution
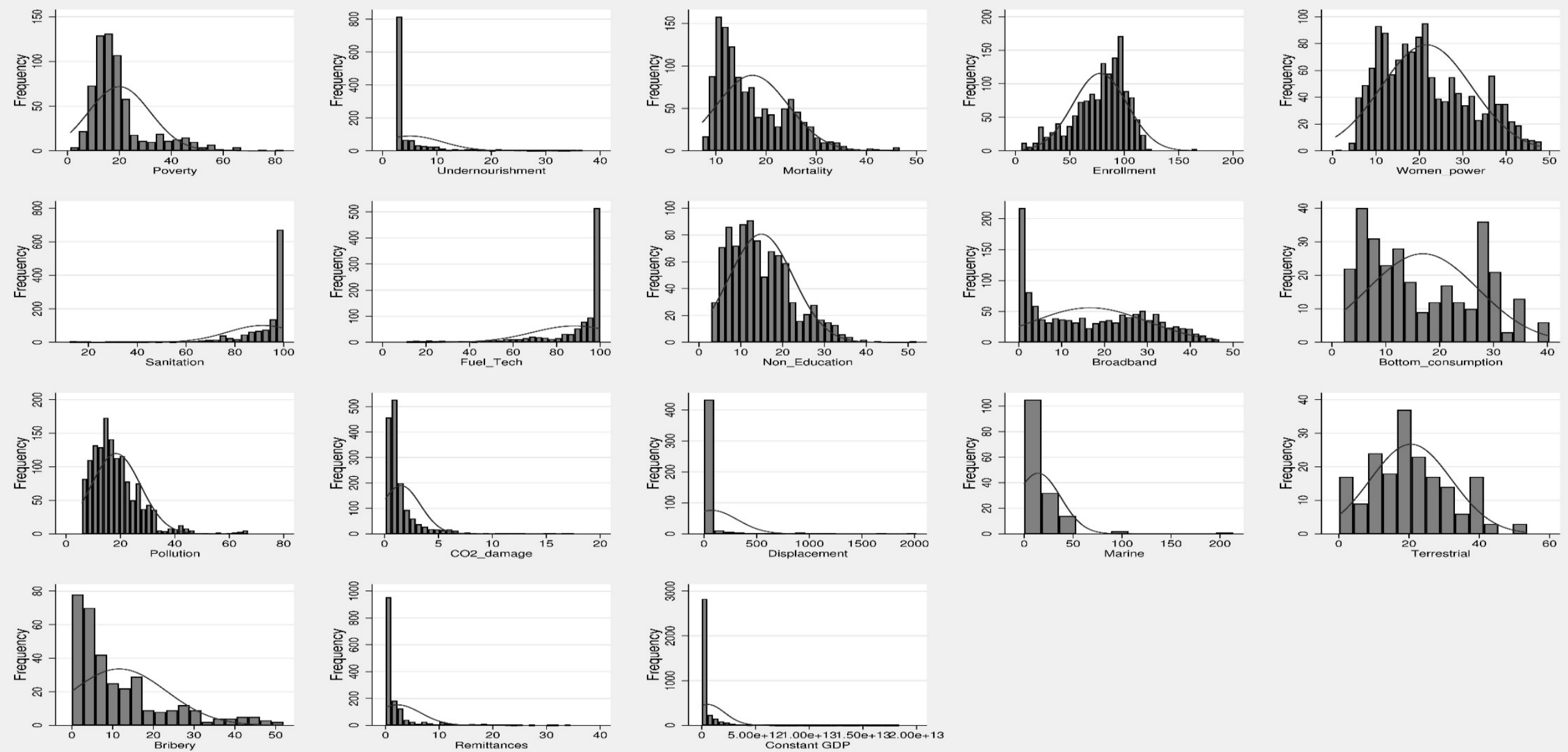

$\mathrm{GDP}=$ gross domestic product.

Note: Descriptions of variables and their units are in Appendix. 
Figure A2. Histograms of sustainable development goals and economic growth (in natural logarithm)

In natural logarithm form, most of sustainable development indicators and GDP show normal distribution. Though it is not the case for all, accessing their association between sustainable development goals and GDP in logarithm form are better-suited than in their raw units.
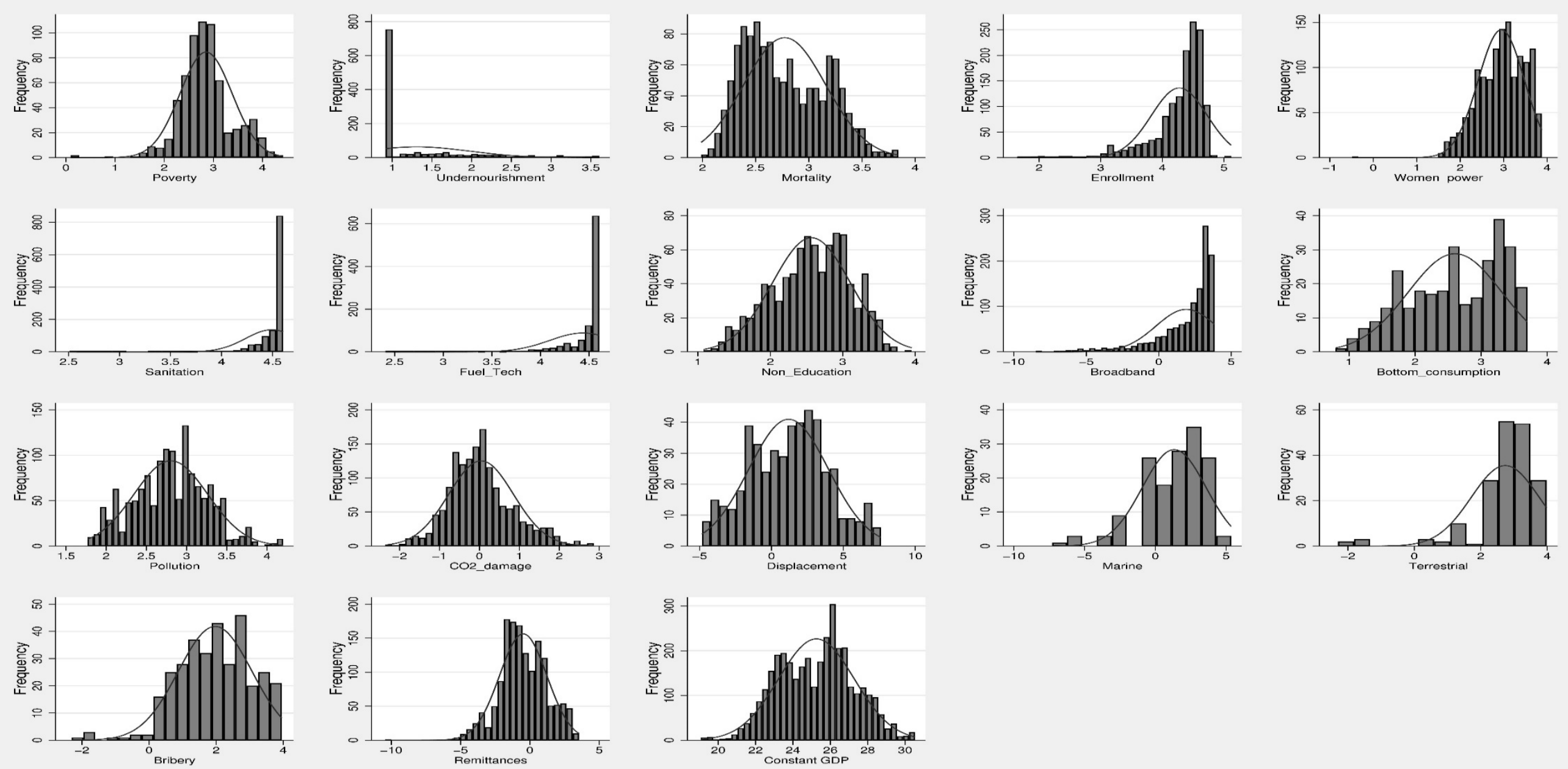

GDP = gross domestic product.

Note: All sustainable development goals and gross domestic product are in natural logarithm. 


\section{REFERENCES}

Aizenman, J., Jinjarak, Y., Nguyen, H.T.K. and Park, D., (2021). Large Fiscal Episodes and Sustainable Development: Some International Evidence (No. w28740). National Bureau of Economic Research.

Alesina, A., \& Ardagna, S. (2010). Large changes in fiscal policy: taxes versus spending. Tax policy and the economy, 24(1), 35-68.

Alesina, A., \& Perotti, R. (1995). Fiscal expansions and adjustments in OECD countries. economic policy, 10(21), 205-248.

Blanchard, O. (1993). Suggestion for a new set of fiscal indicators. OECD Working Paper.

Gupta, S. (2021). Fiscal Adjustment and Growth in IMF-Supported Programs. International Monetary Fund IEO Background Paper No. BP/21-01/03.

Salmon, J., \& de Rugy, V. (2020). Debt and Growth: A Decade of Studies. Mercatus Research Paper. 